Historic, Archive Document

Do not assume content reflects current scientific knowledge, policies, or practices. 



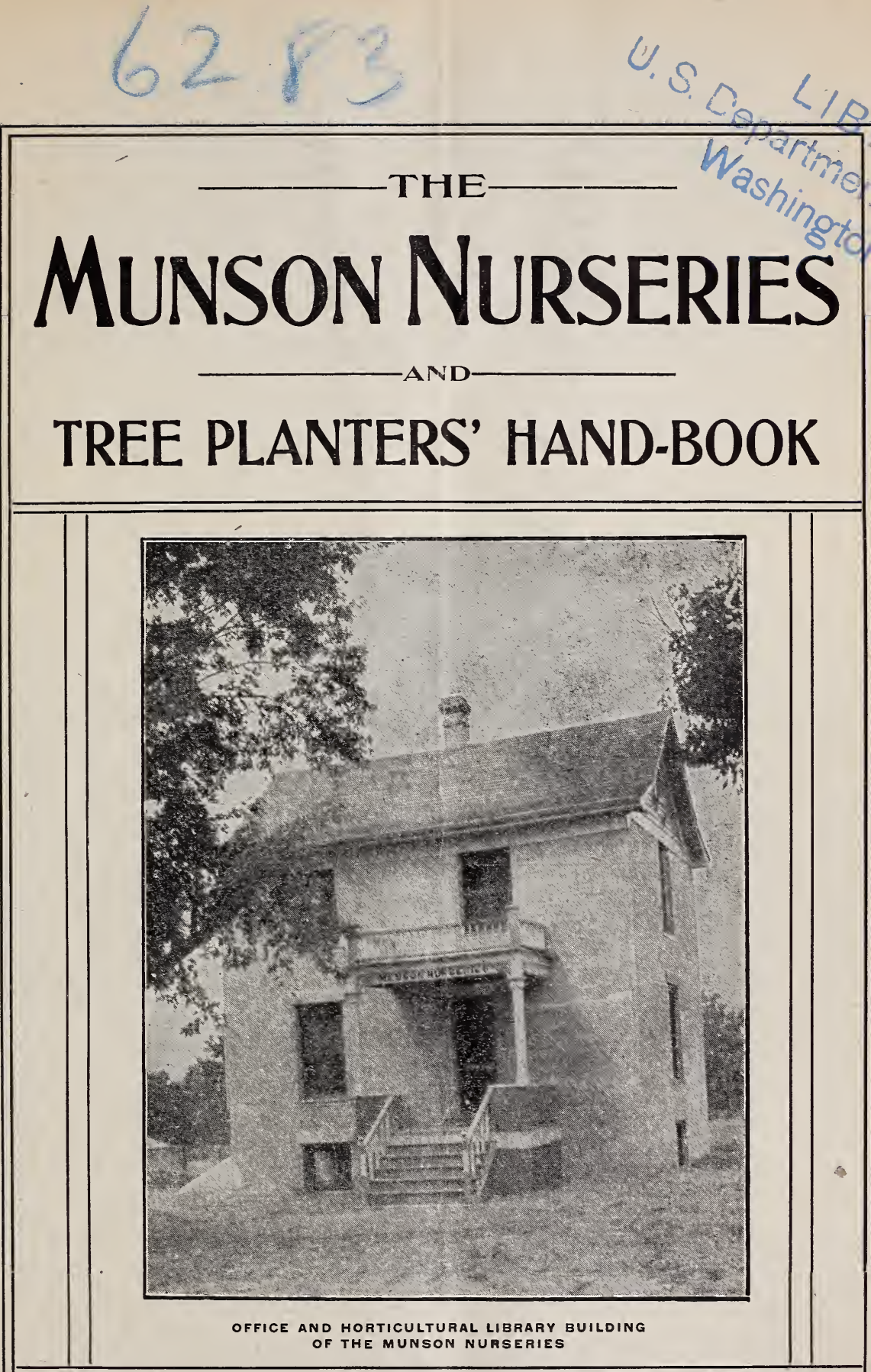

\begin{tabular}{|l|l|l|}
\hline 1905 & $\begin{array}{c}\text { T. V. MUNSON \& SON } \\
\text { DENISON, TEXAS }\end{array}$ & 1906 \\
\hline
\end{tabular}

GREELEY PRINTEAY OF BT. LOUIB 


\section{HORTICULTURAL INFORMATION}

So many of our customers write us for horticultural information (which we have ever most gladly given by letter, until the questions have become too numerous for us to longer thus answer), that we have after careful examination, selected the following list of works of most approved authorslip, and arranged to mail direct to those ordering, at publishers' prices given below.

These books answer your questions in the best manner. This catalogue also contains a vast amount of information, and, if carefully studied, will answer a large number of questions. If, however, neither the catalogue nor the books cover your questions, we will gladly answer them, provided $\$ 1$ is sent to cover time gathering information, etc. To customers sending cash orders, we will make no charge to answer their questions. In writing questions, put them on separate paper and distinct from the order.

Nearly every one of these books is profusely illustrated.

AMERICAN GRAPE GROWING AND WINE MAKING. Prof. Geo. Husmann, revised...........\$1 50

AMERICAN FRUIT CULTURIST. J. J. Thomas, The standard work $\ldots \ldots \ldots \ldots \ldots \ldots \ldots \ldots \ldots \ldots \ldots$

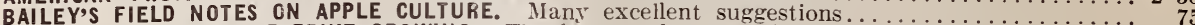

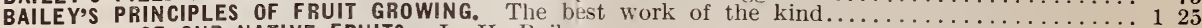

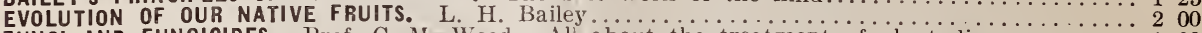

FUNGI AND FUNGICIDES. Prof. C. M. Weed. Ali about the treatment of plant diseases......

GRAPE CULTURIST. A. S. Fuller. A well-known standard work . . . . . . . . . . . . . .

FERTILIZERS. E. B. Voorliees. Director N. J. Agr. Experiment Station. . . . . . . . . . .

HARRIS, TALK ON MANURES. Treating the entire subject in a practical way $\ldots \ldots \ldots \ldots \ldots \ldots \ldots$

HENDERSON'S PRACTICAL FLORICULTURE. The learling work of this class $\ldots \ldots \ldots \ldots \ldots \ldots \ldots \ldots \ldots$

INSECTS AND INSECTICIDES. Prof. C. M. Weed. The best method of fighting insects........

IRRIGATION FARMING. Lute Wilcox. Best book on the subject. Profusely illustrated........

MARKET GARDENING AND FARM NOTES. Landreth. Well adapted to the South.............

LANDSCAPE GARDENING. Prof. F. A. Waugh. How to lay out and plant your grounds...........

PLUMS AND PLUM CULTURE, Prof. F. A. Waugh. Highly illustrated. Superb..............

PRINCIPLES OF PLANT CULTURE. Prof. E. S. Goff. Everyone should understand .......................

THE ORCHARD AND FRUIT GARDEN. E. P. Powell. A valuable work for the beginner, and practical

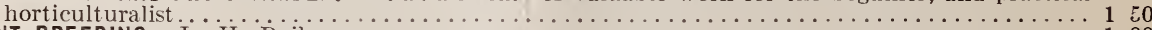

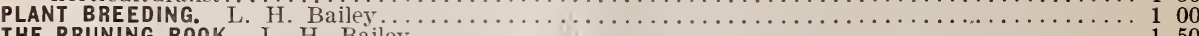

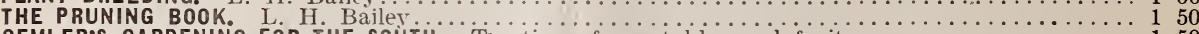

OEMLER'S GARDENING FOR THE SOUTH. Treating of vegetables and fruits . $\ldots \ldots \ldots \ldots \ldots \ldots \ldots \ldots \ldots$

SMALL FRUIT CULTURIST. A. S. Fuller. Covering all classes of small fruits $\ldots \ldots \ldots \ldots \ldots \ldots \ldots 150$

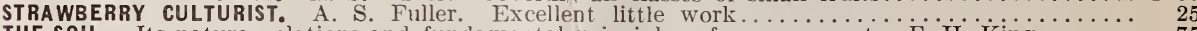

THE SOIL. Its nature, relations and fundamental principles of management. $\mathrm{F}$. $\mathrm{H}$. King. $\ldots \ldots \ldots$

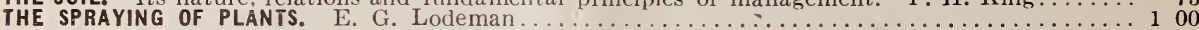

Address: T. V. MUNSON \& SON, Denison, Texas.

\section{CARE OF TREES ON ARRIVAL}

Be careful, in unpacking, to note everything, and IMMEDIATELY "HEEL-IN" IN MOIST SOIL TILL PLANTED, OR PLANT AT ONCE! NEVER ALLOW THE ROOTS TO DRY, OR FAILURE WILL MOST LIKELY RESULT. If the stock is received in a frozen condition, place the bales or boxes in a dark cellar or bury in earth till thawed out.

\section{PREPARATION OF THE TREE FOR PLANTING}

Before planting remove all broken and extra long roots with a sharp knife, cutting from below outward, not from above downward. One-year-old peach or apple trees should be cut back to a naked stem $11 / 2$ to 2 feet high; leave no side branches. Two-vear-old trees should have their branches cut back to their half length or more, the lower less than those above: cutting in shorter as you go upward, and leaving the leader the longest. Plant as deep as the trees stood in the nursery row, excepting dwarf pears and cherries, which should be planted sufficiently deep to cover the stock from two to three inches.

\section{PLANTING THE TREE}

The ground should be thoroughly plowed and subsoiled at least fifteen inches deep. If to be set in land which cannot be plowed, dig holes not less than eighteen inches deep and three feet across. Then fill up with rich, mellow earth, but no fresh manure, to such a point that the tree set thereon will stand the same denth in soil, when the hole is filled, as it stood in the nursery row. Lean the tree to the south considerably and fill in among the roots carefully with mellow soil, and when completely covered an inch or two press the soil firmly down with the foot, after which level up the hole with loose soil, which should not be tramped. If the soil is dry, pour in a bucketful or two of water before filling the hole, and when settled away level up with loose soil. Keep the soil thoroughly pulverized about the tree, and free from weeds during the growing season. Do not water through the summer time by pouring water ON TOP of the ground,but dig trenches around the tree and fill with water every evening until ground is thoroughly saturated below the roots; then no more watering will be needed for two weeks. Partial surface watering kills more trees than it saves. Water only in drouth, when trees show need of it.

For more detailed information on this subject and on future care of the trees, we respectfully refer you to American Fruit Culturist or Bailey's Principles of Fruit Culture, found in the list of books named above. 


\section{$\approx \approx$ INTRODUCTORY}

\section{To Our Customers :}

THE FOLLOWING CAREFUL, TRUTHFUL DESCRIPIIONS are of far more value in making successful selections than would be the grandest set of pictures that could be executed. Therefore, study the descriptions, and preserve this Catalogue, for it will be found a most valuable horticultural work of reference. Our methods of propagation are those pursued by the largest, most intelligent and most successful planters of commercial orchards.

THOSE VARIETIES THROUGHOUT THE CATALOGUE, outside of our special list of Grapes, preceded by (*) were introduced by us after careful testing, and we are proud of them. They are generally making excellent records, and some have become recognized standards.

IN SOME CASES varieties heretofore included in our Catalogue are omitted. Some of these are dropped, as others included are better for the same season, and of some we have no stock to offer this year; such may be inserted when we again have stock of them. Please do not order varieties not named in this Catalogue

WHILE WE HAVE A REPUTATION FOR MAKING A SPECIALTY OF GRAPES, we have by no means neglected other departments or classes of fruits in our line of business. All have had the same vigilant care in testing, selecting and propagation, so that we will be found up with the times in all things.

IN OUR EXPERIMENTAL DEPARTMENT we systematically test all new, very promising varieties as they come out, and ourselves originate numerous varieties of grapes, plums, persimmons, etc. By carefully combining the best strains, and testing for a series of years in various localities, we from time to time introduce those proving superior to others in cultivation of the same season.

CAUTION.-We employ no traveling agents. Those claiming to be our traveling agents are frauds, and should be shunned. We have learned of a number of such operators, and have advertised them for the protection of planters. We never could see any benefit to the planter to be importuned by oily-tongued "agents," out of planting season, with highly exaggerated pictures, samples and deceptive speech, into giving orders at two to four times the prices that the same or better varieties can be ordered direct from reliable, reputable and responsible nurseries, and whose carefully prepared catalogues enable one to order far more intelligently and profitably; hence we prefer DIRECT dealing.

\section{CERTIFICATE OF INSPECTION}

Our nurseries have been inspected by the State Inspector for San Jose scale and other dangerous insects and diseases, in compliance of the laws of Texas, and have been found free of such troubles. A certificate of the inspector will accompany every sale and shipment as required by the law.

TELEPHONE connection, local and long distance. Address:

T. V. MUNSON \& SON.

Denison, Texas.

\section{TERMS, CONDITIONS, SHIPPING, ETC.}

\section{Before ordering be sure to read the following, to avoid delays and confusion.}

I. CASH (by Draft, Money Order or Registered Letter) with order will secure prompt filling. No goods shipped unlesS CASH or SATISFACTORY SECURITY ACCOMPANIES the order. If personal checks are sent, include 15 cents for collection, which amount they cost us. Orders held until personal checks are collected. Time, risk and expense saved by remitting by postal or express order or bank draft. Please use order sheet in Catalogue.

2. TO SECURE GOODS NOT WANTED SENT AT ONCE, send one-half the cost with the order. No reserve will be made otherwise. GOODS WILL BE SHIPPED "C. 0. D." only when one-half payment is sent with order, or satisfactory proof of reliability is furnished.

3. OUR RESPONSIBILITY CEASES after delivery, according to the prices and specifications on next page. under "We Prepay Freight" and "Prices," except for mistakes in filling, which must be reported IMMEDIATELY after receipt of goods, to admit of adjustment. A double system of checking is employed in putting up orders, so that mistakes are rare, and sometimes customers complain of an error and afterwards find it was their own mistake.

4. EVERY CARE IS TAKEN to secure safe and prompt transportation. GOODS ARE CAREFULLY packed in moss or straw, well baled or boxed.

5. IT IS ALWAYS BETTER TO SHIP BY EXPRESS, unless the amount of stock is large. Nursery stock goes by express at especially low rates. In 1905 the railway commission reduced the express rates on nursery stock 8 per cent off the former low special rate on nursery stock.

6. GIVE EXPLICIT DIRECTIONS FOR SHIPMENT. - When such are not given we shall use our best judgment in selecting a route, but will not be responsible for loss thereby, excepting on goods on which we prepay freight. See "We Prepay Freight." Shipping farilities in every direction from Denison are excellent, on the M., K. \& T., T. \& P., H. \& T. C., and "Frisco" railroads, and all connecting lines. 
7. CUSTOMERS WILL GENERALLY BE MOST SUCCESSFUL in getting desirable assortments by leaving the selection, in part at least, to us, as we have much experience in testing and growing for market; but we desire everyone to have his or her choice as nearly as possible.

8. IT IS TO OUR OWN INTEREST to give customers the best terms and selections possible. But we cannot prevent Drouths, Severe Winters, Early and Late Frosts, Insects and Rabbits, etc., from cutting, nor plants from dying by bad treatment in other hands, HENCE WE NEVER INSURE TREES TO LIVE AFTER LEAVING OUR POSSESSION, but we do deliver stock in good order, true to name. In case we fail in these we replace at once or refund money. After stock is accepted, we replace none that may die after planting. Unsatisfactory stock must be reported at once on receipt of same to secure adjustment.

9. WE ARE RESPONSIBLE TO ALL OF OUR CUSTOMERS, and to them only, for the character of the goods, and to them or their forwarders-express and railway companies-we guarantee to deliver stock in good order, true to name. With such delivery our responsibility ceases.

10. CLUB ORDERS.-Many responsible persons get up Club Orders in their own communities, and send in to secure club rates. Such trade is respectfully solicited. Club rates will be given on application. This is the nearest approach we make to agency work.

II. SUBSTITUTION.- - If it is not explicitly stated in the order that no substitution is permitted in case the variety ordered is sold out, we shall consider permission to substitute granted, and then put in place of the variety ordered another, always with its correct name, and one of equal or better value, unless such is not in stock, when the variety will be left unfilled and the money for it returned.

12. In order to secure what you wish, send your order early in the season, before stock is sold Orders received late in the season may expect to find assortments broken in any nursery.

13. Please do not order articles not named in Catalogue. We catalogue only what we have for for sale, and aim to sell only what we produce.

14. SEASON FOR SHIPPING AND TRANSPLANTING.-We begin digging Strawberry Plants October 151 NOT EARLIER, and other stock November 10, and continue almost uninterruptedly to dig and ship unti March 10, November, December and February being the best months in which to transplant in the South

15. TREES AND PLANTS BY MAIL.-Small fruit trees and shrubs, one-year grape vines, strawberry, raspberry and blackberry plants can be sent by mail in packages of less than four pounds each, at the rate of one-cent for every two ounces. To cover this and packing, remit for every tree, shrub or grape vine, 5 cents each when six or less are ordered, 4 cents each when six to twelve are ordered, and 3 cents each when more than twelve are ordered. For berry plants remit 10 cents per dozen, 20 cents for fifty and 35 cents per hundred. For small orders to go long distances this is a very cheap and satisfactory method.

16. BUDS, CIONS AND CUTTINGS.-We do not offer these for sale.

17. WE PREPAY FREIGHT OR EXPRESS on all orders of $\$ 5$ or more, when selected from "prepaid scale," to any railway or express station within the States of Texas, Louisiana, Arkansa $s$, Indian Territory Oklahoma Territory, Kansas and Missouri, south of the Missouri river, when such prices are remitted to secure it, which are those stated throughout the Catalogue as "PREPAID" prices. On orders of \$5 or less, or on all sized orders to other States than those named we do not prepay, but make allowance by filling at a less rate, which will be found in the Catalogue as the F. O. B. Denison rate. We will prepay on orders of $\$ 5$ or less if money is sent for that special purpose. We do not prepay on orders of $\$ 5$ or more when the prices are taken from the "F. O. B." scale.

18. WHEN TO USE "PREPAID" AND "F. O. B." SCALE OF PRICES.-Use the "prepaid" scale if orde ${ }^{T}$ is $\$ 5$ or more and you want us to pay transportation charges. Use " $F$. O. B." scale on all orders of \$5 or less. Use "F. O. B." scale on orders of $\$ 5$ or more when you desire to pay the transportation charges at your end of the line. Customers in making orders of $\$ 5$ or more have the choice of either scale of prices.

19. HOW TO USE OUR SCALE OF PRICES. - Throughout the Catalogue each variety or class will be priced for a single tree or plant, for twelve such trees or plants, or for 100 such trees or plants. If only 1 to 5 trees of a class are wanted, use the "each" price as a basis; when 6 to 36 of a class are wanted, use the "dozen" rate as basis; when 37 or more of a class are wanted, use the " 100 " rate as basis; for example:

\section{IF YOU WANT TO PAY EXPRESS CHARGES- "F. O. B." SCALE.}

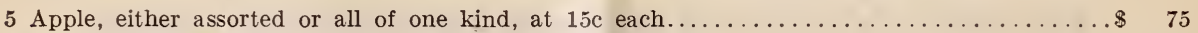

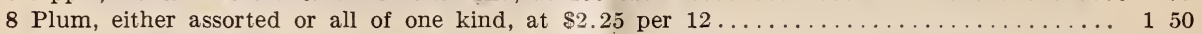

60 Peach, either assorted or all of one kind, at $\$ 8$ per $100 \ldots \ldots \ldots \ldots \ldots \ldots \ldots \ldots \ldots \ldots$

Total. .

SAME BILL IF YOU WANT US TO PREPAY CHARGES- "PREPAID" SCALE.

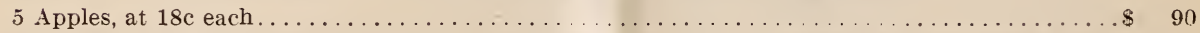

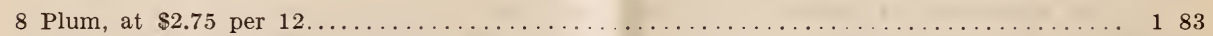

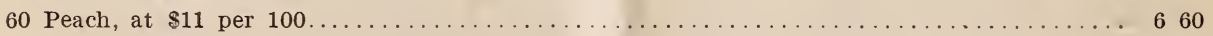

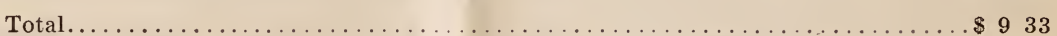

20. If the order amounts to $\$ 20$ or more figure all items at the 100 rate, or the lowest rate found in Catalogue, regardless of number taken of each variety.

21. WHOLESALE ORDERS.-When larger quantities of goods of any class or variety are wanted than are priced in Catalogue, please send list of varieties and number of each desired, for special quotations. We invite comparison of prices and stock with any and all reliable, first-class nurseries. We do not pretend to compare prices of our carefully grown, reliable stock with job-lot prices of "Tom, Dick and Harry," who have a "dead horse" to sell. Ours are living prices on good, reliable stock. Unreliable, poorlygrown stock is dear as a gift. 


\section{APPLES}

Plant Apple Trees in the South 20 feet apart north and south by 30 feet apart east and west, requiring 73 trees per acre. Best corn or cotton sandy land is suitable.

Read Bailey's Field Notes on Apple Culture, price 75c. (See 2d cover page.)

\section{PRICES - Unless 0therwise Noted}

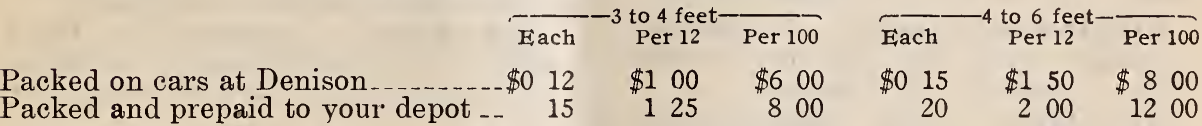

Prepaid prices are for orders of not less than $\$ 5$, and only to places named in paragraph 17 , page 2, which please fully read.

This list has been well tested, and found uniformly and continuously successful in the Southwest. The varieties ripening in June and July are the most successful in South Texas. Late varieties do little or no good there. All the varieties named succeed well in Northern Texas and Indian Territory. The extra early apples should be more extensively planted in the South, as they are one of our most certain and profitable fruits.

\section{IN ORDER OF RIPENING}

\section{JUNE IN TEXAS}

DUCHESS OF OLDENBURG. Prolific, striped medium; good, tart; market.

EARLY HARVEST. Vigorous, abundant, yellow, large; good, tart; table, cooking.

RED ASTRACHAN. Vigorous, productive; red, large; tart, market.

RED JUNE. Slow, prolific; red, small; good, tart; market, table. One of the most valuable for heavy planting in the South.

FANNY. New, vigorous; productive; red, large; excellent; market, table.

EARLY PENOCK. Very large, striped; vigorous, prolific.

\section{JULY}

SAN JACINTO. Like an enormously large Red June apple, of which it appears to be seedling, coming in just as the Red June goes out. Tree vigorous and prolific; very productive. A variety of the highest merit both for market and table. Fruit hangs to the tree remarkably well and a fine keeper for an early apple. Fortunate will be the orchardist who gets an early start of this apple. $25 \mathrm{c}$ each; $\$ 2.50$ per dozen.

SUMMER ROSE. Medium, bright, striped, very prolific.

SUMMER QUEEN. A b u $\mathrm{n}$ d a $\mathrm{n} \mathrm{t}$, striped; large; good, table, market.

AMERICAN SUMMER. Productive, striped; medium; best, table, market.

ALEXANDER. Very large, conical, striped; vigorous, productive.

GRAVENSTEIN. Large striped apple of most excellent quality; vigorous, prolific.

\section{AUGUST}

BLEDSOE. (Texan.) Very fine, prolific, striped, large; excellent, table, market.

YELLOW HORSE. Very vigorous; abundant; yellow, large; good, culinary.

JONATHAN. Good grower, prolific; red, medium; fine, market.

MAIDEN BLUSH. Vigorous, prolific; cream-blush, large; fine, market, cooking.

DOYLE. Of Texas origin. Large, striped; excellent, prolific.

MRS. BRYAN. A large, brownish, red apple with yellow ground, of excellent quality, ripening just after Jonathan. Originated in Georgia. Highly recommended by Georgia State Horticultural Society.

\section{SEPTEMBER}

RED WINTER. Good, prolific; red, medium; fine, table, market.

TIVENTY - OUNCE. Very large, striped.

\section{OCTOBER AND LATER}

BRADFORD. (Kentucky Sireak.) Strong, abundant; striped, large; very good, market.

WINESAP. Prolific; red, medium; very good, market.

BEN DAVIS. Hardy, vigorous, profuse; striped, large; good, market.

* RUTLEDGE. This variety originated in Travis County, Texas. Tree vigorous and productive; fruit large, handsome, richly striped, resembling the Bradford somewhat, and of still finer quality than that splendid variety; it ripens shortly after the Ben Davis. In this, we believe, we have one of the most valuable of all Southern apples. 
GANO. Vigorous, prolific, bright red large; good, market. This variety is similar in every way to the Ben Davis, but of a rich red all over; very valuable. Renamed by some, "Black Ben Davis."

TEXAS RED. One of the most highly esteemed apples in East Texas. large, striped; fine; excellent keeper.

ARKANSAS BLACK. Vigo ro u s abundant; dark red, medium; excellent market; seedling of Winesap.

KINNAIRD. Strong, spreading tree, prolific; red, large; a superb Southern winter apple; the best of all Winesap seedlings.
WALKER LATE. Large, roundish, slightly flattened; more or less bright striped all over; ripens a month later than Ben Davis and a much better keeper; of extra fine quality; a noble and a very valuable market apple.

YORK IMPERIAL. Large, red, productive; fine market.

SHIRLEY. (Texan.) Vigorous, prolific; striped, medium; excellent.

ARKANSAS. (Mammoth Black Twig.) A splendid, large, dark red Arkansas apple. A fine Winesap seedling.

YATES. Very vigorous, prolific; striped, small; cider or dessert; keeps very late; best quality.

\section{CRAB APPLES}

PRICES $\left\{\begin{array}{l}\text { F. O. B---_-_20 each. } \\ \text { Prepaid } \$ 2.00 \text { dozen. }\end{array}\right.$

2.50 "In orders above $\$ 5.00$ only.

WHITNEY. Vigorous, prolific; striped, large; cider, jelly, preserves.

HYSLOP. Vigorous, prolific; crimson, large; ornamental, preserves.

TRANSCENDENT. Vigorous, productive; leaves out early; medium large; round; yellow, striped with red.

\section{PEAS}

Plant 18 feet apart each way, requiring 135 trees per acre. Pears root very deeply, and succeed on almost any soil if kept free from blight. Except Le Conte and Bartlett, the varieties named below are freest from blight.

\section{PRICES_Unless Otherwise Noted}

Packed and on cars at Denison_._. $\begin{gathered}\text { Each } \\ \text { Per } 12\end{gathered} \quad \begin{gathered}\text { Per } 100 \\ \$ 2\end{gathered}$

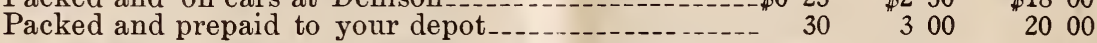

Prepaid prices are for orders of not less than $\$ 5.00$, and only to places named in paragraph 17 , page 2 , which please fully read.

\section{IN ORDER OF RIPENING}

WILDER. Medium pyriform, pale yellow, shaded dark russet red; flesh pale yellow, fine grained, tender, subacid, juicy. Very successful in Texas.

SECKEL. On pear; prolific; brown.

BARTLETT. On pear; prolific; yellow, large; fine, table, market.

BROWN BEURRE. Large, brown; firm; best quality, hardy.

SUPERFINE. Large, yellow, fine quality. Little or no blight.
ANGOULEME. (Duchesse.) On pear; pale vellow; very large; good, market.

GARBER. Similar to Keiffer; but a month earlier.

ANJOU. On pear; brown blush, medium; fine, table. Ripe just before Keiffer.

KEIFFER. On own roots; very vigorous, prolific; yellow; very large; an excellent pear for canning; rarely blights or fails to bear.

\section{QUINCES}

Plant 10 to 12 feet apart each way. Quinces need very rich, deep, well-drained soil; they are better for careful culture.

\section{PRICES}

Packed and on cars at Denison $\begin{array}{rrr}\text { Each } & \text { Per } 12 & \text { Per } 100\end{array}$

Packed and prepaid to your depot (in $\$ 5$ orders or more) $--\quad 20 \quad 175 \quad \begin{array}{llll}71 & 20\end{array}$

MEECH. Very fine and prolific; none better in growth or quality of fruit. 


\section{APRICOTS}

Plant 18 feet apart each way, requiring 135 trees per acre. Succeed best in limestone soils; bloom very early in spring. Should be treated like peaches. Very successful in most parts of the West, on high ground.

\section{PRICES}

Packed and on cars at Denison Each
$\$ 020$

Per 12

Per 100

Packed and prepaid to your depot

Prepaid prices are for orders of not less than $\$ 5.00$, and only to places named in paragraph 17, page 2 , which please fully read.

ROYAL. Early; large, excellent, highly flavored. Ripens with Moorone of the very best.

MOORPARI. Medium, large excellent.

PEACH. Slightly larger than Moorpark; roundish; yellow orange, with brownish orange cheek; rich, juicy and park.

CLUSTER. This valuable variety is claimed to have never missed bearing any season since its introduction. Originated in Texas from seed of Russian Apricot.

\section{CHERRIES}

Plant 18 feet apart each way, requiring 135 trees per acre. Require very best drouth-resisting soil.

$\begin{array}{lrr}\text { PRICES } & \text { Each } & \text { Per } 12 \\ \text { Packed and on cars at Denison } & \$ 250 \\ \text { Packed and prepaid to your depot. } & \$ 25 & 300\end{array}$

Prepaid prices are for orders of not less than $\$ 5.00$, and only to places named in paragraph 17, page 2, which please fully read.

EARLY RICHMOND. An old, popu- ENGLISH MORELLO. Similar to lar, reliable variety; very productive.

BALDWIN. New. From Kansas. Does finely in the dry West and Southwest.

Early Richmond; later.

MONTEMORENCY. Large, round, bright red, acid. Tree hardy and bears early. Good market variety and fine for preserving.

\section{FIGS}

Hardy in South Texas. In North Texas unprotected tops will sometimes winter kill, but when frozen tops are cut off, new shoots will come and bear fruit late in summer of same season. Like rich garden soil. Plant six feet apart. The following are early and prolific bearers:

PRICES, 1-year Trees. $\{$ F. O. B. 20c each. $\$ 2.00$ per dozen. $\$ 15.00$ per 100 .

ADRIATIC. Medium, roundish: yellow skin, pulp red.

BLACK CALIFORNIA. Large, dark purple skin, pulp red.

BRUNS WICK. Very large, pyriform. Skin pale amber, pulp amber; excellent quality and a good canner.

CELESTIAL. Small ovate; skin dark violet amber; pulp deep rose; best quality ; fine for canning.

\section{MULBERRIES}

Plant 20 to 25 feet apart, requiring 109 trees per acre. Flourish in any soil or situation.

\section{PRICES}

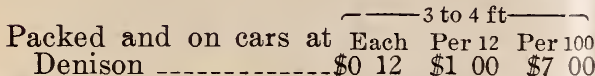

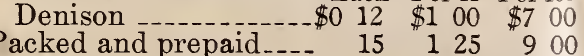

HICKS EVERBEARING. Profuse bearer of fruit for three months; fine grower for shade; the best of all trees for the fowl yard, as the fowls greedily eat the berries.

VICTORIA. One of the best Russian Mulberries yet produced; very fine.

\begin{tabular}{|c|c|c|c|c|c|}
\hline & & & & & \\
\hline $\begin{array}{r}\mathrm{act} \\
2\end{array}$ & $\begin{array}{r}\text { Per } 12 \\
\$ 150 \\
200\end{array}$ & $\begin{array}{r}\text { Per 100 } \\
\$ 100 \\
130\end{array}$ & $\begin{array}{r}\text { Each } \\
\$ 020 \\
25\end{array}$ & $\begin{array}{r}\text { Per } 12 \\
\$ 200 \\
250\end{array}$ & \\
\hline
\end{tabular}

*MUNSON. One of the largest, most prolific and best mulberries of the Russian class. Originated by us, selected from among thousands of varieties grown from seed. The branches in fruit look like ropes of big berries.

See non-fruiting Mulberry under Shade Trees page 26 See Weeping Mulberry, under Shade Trees, page 26 


\section{PEACHES}

Plant 18 feet apart each way, requiring 135 trees per acre. Thrive best on high, well-drained, sandy loam, with clay subsoil, but do well in black lands.

\section{IN ORDER OF RIPENING}

Each "ripening" extends over a period of 10 to 15 days, and embraces white and yellow-fleshed free and cling varieties. where possible. Nearly all the varieties have been critically tested by us along with numerous other kinds, in four successive test orchards, planted and fruited within the past 28 years in different soils and situations. Not a variety is included which has not been tested by experienced and critical orchardists and pronounced valuable for the particular purpose and sections for which it is recommended. Desirable qualities in tree, as well as fruit, have been considered.

Those varieties followed by the letter A only are recommended for amateur or family planting. In size and quality of fruit they are usually the very finest, but not prolific or firm enough, or of the right season for a profitable planting, except in very favorable localities. Those followed by $\mathbf{C}$ are recommended for canning; those followed by $\mathbf{E}$ are recommended for eraporating; those followed by $\mathbf{M}$ are recommended for marketing fresh; those followed by C E M will make an excellent "all purpose" variety.

The letters following the description of each variety refer to the comparative size of the flower. The letter $\mathbf{S}$ indicates small flowers; $\mathbf{M}$ medium flowers; $\mathbf{L}$ large flowers, and VL very large flowers. As a rule the large-flowered varieties are the surest fruiters. The varieties named throughout this list, however, are all good bearers.

While some of the following list do not succeed in the Gulf regions, the following have been found to do well there: Mamie Ross. Family Favorite, Elberta, Bequett Free, Texas King, Carman, Ray, Superb and Bequett Cling. The entire list succeeds well in all other parts of the Southwest.

WE CHALLENGE THE WORLD TO EXCEL THIS LIST OF PEACHES.

\section{PRICES - Except where noted}

$$
\text { Each } 3 \text { to } 4 \text { feet- } 12 \text { Per } 100
$$

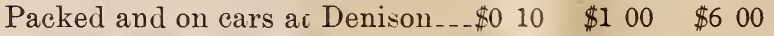

Packed and prepaid to your depot_ $\quad \begin{array}{lllll}15 & 1 & 25 & 8 & 00\end{array}$

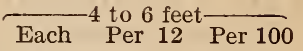

$\$ 015 \$ 150 \quad \$ 800$

$20 \quad 200 \quad 1100$

Prepaid prices are for orders of not less than $\$ 5.00$, and only to places named in paragraph 17, page 2, which please fully read. Higher priced varieties include prepayment if in prepaid orders.

\section{I}

Ripening at Denison May 20 to June 10.

VICTOR. m. Regarded as earlier, better and finer than the Sneed. 1.

SNEED. m. Earlier, larger and better than Alexander; less inclined to rot. 1.

ALEXANDER. m. Well-known old standard; extra early. 1.

EARLY WHEELER. (Trademarked), Introducer's description. "The earliest first-class peach yet introduced. A perfect shipper; ripe six weeks earlier than Elberta; large size; color creamy white, overspread with a beautiful bright glowing red; quality good. Quite similar in size, color, texture and quality to Old Mixon Cling." We consider this description accurate, having seen the fruit two successive seasons. Originated by E. W. Kirkpatrick of Texas.

Price, 50 cents each; $\$ 5$ per dozen.
DEWEY. The best early yellow freestone, ripens little earlier than Triumph. Very little subject to rot. Being similar to but better than Triumph we have dropped the latter in favor of the Dewey.

PAIRSON EARLY. We secured this peach from a large orchardist in Phoenix, Arizona. It is a large, bright yellow freestone, with rich red cheek of excellent quality. It is a sure and abundant bearer, ripening just after the Dewey. Sample of it sent to World's Fair, St. Louis, at same time the Guinn peach from East Texas was shown in the Exposition, attracted much attention, being considered a finer looking and better variety than the Guinn.

Price, 50 cents each, $\$ 3.00$ per 12 .

\section{II}

(*1)R. BURTON. A variety produced by Dr. E. L. Burton of Grayson County, Texas. The original is yet very vigorous, bears annually heavy crops, and is about 18 years old. It is of the North China class, very similar to Mamie Ross in vigor, certainty and abundance of bearing, has large flowers. It is, however, a much superior fruit to Mamie 


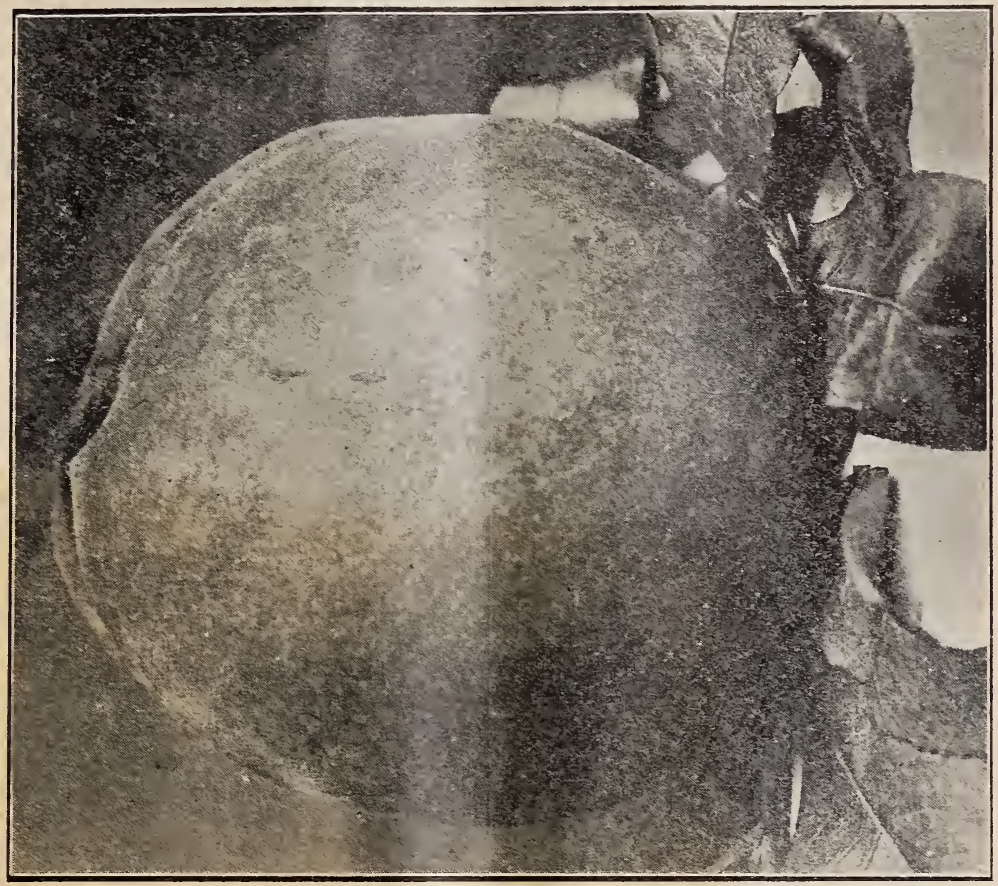

\section{MUNSON CLING}

(See page 8 , Ripening, T.)

Ross. It is a perfect freestone, of rathel larger size than Mamie Ross, of same shape, oblong with smaller seed, much firmer and far more color-onehalf covered with rich crimson-and quality of the finest, far superior to Mamie Ross, in fact the best and handsomest peach of its season, which is at least a week earlier than Mamie Ross. This has been marketed for several years and commands readily a better price than Mamie Ross. It will certainly take high rank as a commercial peach. TVe take great pride in introducing this noble peach. We have seen the tree in fruit and ate the fruit in critical comparison with Mamie Ross growing by its side with equal advantages in soil and culture. 1 .

Price $\$ 1.00$ each; $\$ 6.00$ for 12 .

RAY. $m$ a. Origin in East Texas. Of Mamie Ross type but with more color and less attacked by rot. Equally large as Mamie Ross, to which we consider it a superior peach. 1 .

MAMIIE ROSS. a m. Very large; blush; white flesh, semi-cling, prolific; very valuable. 1 .

HYNES' SURPRISE. m. True free- stone when ripe; resists rot better than Hale's Early, which it resembles. 1.

*BISHOP. m. Very large, crimson, white flesh, free; a very valuable market sort, sure and prolific. $m$.

CARMAN. c $\mathrm{m}$. Origin in Limestone County, Texas. Large, of fine appearance and quality, firm, free from rot, highly praised, best of its season. 1 .

TEXAS KING. From East Texas. A peach of Mamie Ross type of better quality. The hardiest in bud of any variety recorded, making it a very sure bearer. Fully as large and well colored as Carman. 1.

\section{III}

Ripening at Denison June 10 to July 10

HYNDS' YELLOW. m c. Medium to large size, yellow, free, of very fine flavor. Sure and abundant. Ripens with Mt. Rose and takes place of Yellow St. John. A very valuable yellow variety and splendid shipper to precede Elberta. m.

MOUNTAIN ROSE. c e m. Large round; white flesh; red cheek; free. s. 


\section{IV}

* FAMILY FAVORITE. m e c. Large; white flesh, red cheek; free, sure, prolific; seedling of Chinese Cling. This is making a most favorable record everywhere. Better than Thurber. $m$.

FOSTER. a e c m. Earlier and finer quality than Early Crawford; very handsome. More certain cropper. Inferior to Elberta in every way excepting quality, to which it is very superior. s.

\section{$\mathbf{V}$}

Ripening at Denison July 5 to 20

GEN. LEE. a m. Seedling of Chinese Cling, but earlier and more prolific; better; white, cling. vl.

ELBERTA. m c e. Very large; yellow, red cheek; free, firm, sure, prolific; best of all. For vigor, certainty and abundant bearing this variety has no superior; for fine appearance, good shipping qualities and ready selling, for canning and evaporating, it stands with" out a peer among old kinds. Dispenses with Crawford. $\mathrm{m}$.

*MUNSON CLING. Selected seedling of Elberta among hundreds grown from select seed. Equally large with Elberta, more spherical, with a short beak. Firm, yellow flesh of finest quality. Surface mostly covered with bright red, very handsome. An immensely superior variety to Chilow. Ripens with Elberta. This fills the place with those desiring a cling to match the Elberta, so often asked for. m.। 75 cents each, $\$ 6$ per dozen.

*SUPERB. $\mathrm{m}$ c e. Seedling of Early Rivers, crossed with Mountain Rose. Pure freestone; white flesh, red cheek; large and showy; a very prolific and profitable peach; finest quality. Supersedes the Old Mixon Free. This peach is making a record where others fail as a certain bearer and valuable market variety. 1 .

CHINESE CLING. a. Largest size; oblong; greenish cream, faint blush. 1 .

\section{VI}

Ripening at Denison July 20 to Aug. 10 *MUNSON FREE. Selected variety from among several hundred Elberta seedlings, grown from selected seed. The fruit is still larger than the Elberta as eighty specimens filled a bushel; more highly colored, more oblong and of better quality, flesh yellow. More prolific and hardy in bearing. Ripens about a week later than Elberta. Very firm; fine for shipping. We believe that no finer or more valuable peaches than the Munson Free and Cling were ever introduced. m. $75 \mathrm{c}$ each, $\$ 6$ per dozen.

SYLPHIDE. m c. Cling; large, white flesh, red cheek; prolific, sure; seed- ling of Chinese Cling, than which it is more prolific and of better quality. 1 .

BEQUETT FREE. $m$ c e. Largest size; white flesh, red cheek; productive, firm, superb; possesses Chinese blood; a sure bearer. s.

ORANGE. c m. Large, clear, yellow cling, sweet, rich, juicy, prolific. $\mathrm{m}$.

STUMP. $m$ c e. Large white flesh; red cheek; free; reliable. s.

BEQUETT CLING. c m. Very large; white flesh, red cheek; productive, fine; as large as Chinese Cling and possesses some Chinese blood. Supersedes the Old Mixon Cling. s.

\section{VII}

Ripening at Denison August 10 to 25

*BLANCHARD. . Originated with C. C. F. Blanchard of Runnels County, Texas. Cling, very large, about same as Chinese Cling, white with rich red cheek, firm; splendid shipper and quality unexcelled. Having seen and eaten this peach, we know it to be of the finest in cultivation, and its late season makes it very desirable, as it comes when there are no other very fine peaches ripening. $\$ 1$ each.

*TIEBOUT. Originated with V. J. Tiebout of Ellis County, Texas. Free, largest size, rich orange yellow with dark red cheek covering one-half; flesh of the finest quality, firm, buttery; a splendid shipper; seed small. This makes a splendid mate for the Blanchard. They are two of the finest peaches known to us. In size they class with the Elberta and are sure to take high rank when better known. Hundreds of new peaches are brought to our attention for testing, but rarely do we find any to fill a new place in our superb list. The very fact that we permit these to enter our list is their highest praise. $\$ 1$ each .

*COLUMBIA. c e m. Large, dull, orange-yellow, mottled with red; free; sure, of rich buttery quality. 1 .

CROTHERs. m e c. Large, white flesh, red cheek; best, productive, superior to Ward's Late. $\mathrm{m}$.

*RAISIN. a m. Of the Indian Cling type, crossed with Heath. Dull white, splashed with red; large, juicy, prolific; splendid. The finest in quality of any cling known to us. 1.

\section{VIII}

RINGGOLD. c m. A greatly improved seedling of Heath Cling; superb white, sweet. s.

*CRIMSON BEAUTY. m c. Very large; white flesh, crimson surface; cling; prolific. 1 .

SALWAY. c e m. Large, yellow freestone; red cheek. Very valuable market peach. s. 


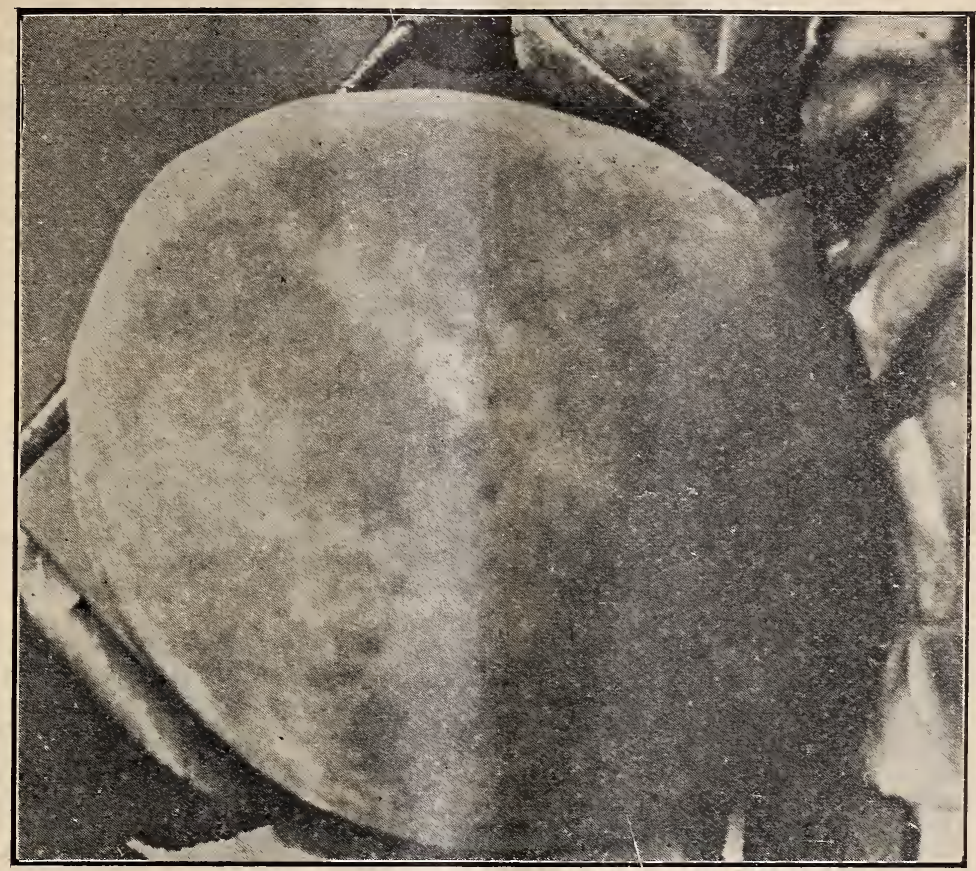

MUNSON FREE

\section{IX}

Ripening at Denison September 10 to 25

HENRIETTA. m c. Very large, cling; yellow, crimson cheek; sure. Valuable late market. s.

* BONANZA. c e m. Very large; white flesh; red cheek; free; prolific, vigorous. $\mathrm{m}$.

*DULCE. Originated in the yard of B. C. Murray of Denison, Texas, and named for his daughter. The same description of the Tiebout (which see in ripening VII), but ripening a month later. We have frequently seen the fruit and eaten of it and know it to be without an equal for its season. So far it has always ripened out perfectly and in quality is unexcelled. It gives us
Ripening VI.)

great satisfaction to introduce these three remarkable peaches, viz.: Blanchard, Tiebout and Dulce. $\$ 1$ each.

\section{X}

Ripening at Denison into October

*BARNES. a m. A fine, very late yellow cling of Indian type. Originated in Bell County, Texas, by Barnes Parker. 1.

*BELL OCTOBER. c e m. Large, rich yellow, red cheek; freestone; of finest quality. Origin, Denton County, Texas. s.

*SUCCESS. e c m. Prolific, sure; latest yellow, freestone, large, excellent. Originated with us and offered with confidence in its merits. 1 .

\section{PLUMS}

We pride ourselves on this list as being the most valuable and best arranged ever offered for sale.

Plant 18 feet apart each way, requiring 135 trees per acre. Succeed on thinner land than the peach, with more clay, and thrive where the peach will. Varieties of each class generally stand in order of ripening. List of varieties described below is arranged according to specific: character. All succeed well nearly everywhere.

\section{Read Plums and Plum Culture (Waugh), \$1.50.}

\section{PRICES_Except where noted}

Higher priced varieties go in prepaid orders without extra cost.

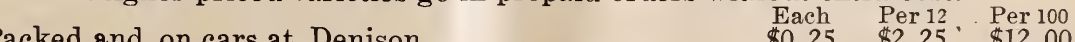

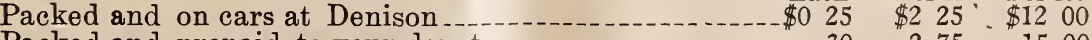

Packed and prepaid to your depot...... $30 \quad 250$

Prepaid prices are for orders of not less than $\$ 5.00$, and only to places_named in paragraph 17 , page 2 , which please fully read. 


\section{PLUMS CONTINUED \\ JADANESE VARIETIES AND THEIR HYBDIDS}

*FUNK. An Abundance-Chickasaw hybrid. Tree vigorous and healthy, upright, prolific. Fruit above medium, heart-shaped, bright red; cling. Extra quality for so early ripening. Ripens the earliest of any plum known to us. So far not attacked by rot or curculio when growing among trees much affected. $50 \mathrm{c}$ each; $\$ 4$ dozen.

RED JUNE. Large size, slightly conical; solid, dark red color, with yellow flesh; ripens early; sure bearer; very valuable for market.

GONZALES. Fruit very large, meaty, of a brilliant red; finest of flavor; good shipper and keeper. Tree very strong and immensely productive. Very valuable.

CHALCO. Hybrid of Simon with Burbank, by Luther Burbank. Tree thrifty, upright, prolific; fruit large, flattened, red tomato color; meaty, firm; stone nearly free, small; quality extra, high flavor, similar to Simon.

ABUNDANCE (Botan): Vigorous, upright; large, purple, good; very prolific, sure; best of all Japan varieties.

BURBANÍ. Very vigorous, spreading; very large, purple; profitable.

NORMAND (Yeddo). We have fruited this several years by the side of the Georgeson, or Mikado, which has been given as a synonym, but find it distinct and a far better plum than the Georgeson; in fact, one of the very best of the Japan varieties. Tree stocky, vaseshaped in growth; exceedingly prolific; fruit very large, golden, broad, heartshaped; meaty, firm, sweet, rich flavor; stone small, nearly free. Ripe just before Chabot.

SATSUMA. Large to very large; dark purple skin, flesh and juice very firm, splendid for market and preserving. Blooms very early and ripens after the Burbank. Highly adapted for Western Texas.

CHABOT (Douglas, Hytankayo). A strong, upright tree; fruit very large, crimson, with white bloom; excellent, prolific, valuable.

WICIKSON. One of Burbank's most remarikable hybrids, between Kelsey and Simon Plum; very large, heart-shaped; dark crimson; firm, of finest quality. Bloom very early. Nothing finer in appearance or quality is known among plums.

\section{WILD GOOSE TYPE OF THE CHICKASAW CLASS}

Bloom early to medium.

MILTON. Wild Goose, crossed with some Americana variety. Better than Wild Goose, equally as large; hand-
Prices on Page 9.

some and productive; red; excellent. Very early, although it blooms late. Persistent to the tree after ripening. Free from curculio and rot.

CLIFFORD. Seedling of Wild Goose Tree vigorous, spreading with somewhat weeping habit; productive; fruit large, slightly necked, bright red with white dots; meaty, rich pineapple flavor; very handsome and profitable. Ripe just before Whitaker. Sells at the highest price.

AMERICA. A hybrid of the Robinson with the Abundance, by Luther Burbank in 1898. Tree very thrifty, symmetrical, spreading; fruit medium to large, bright golden ground with pink cheek, dotted white; flesh firm; stone medium to large, cling. Considered one of Burbank's best productions. Very valuable.

WHITAKER. Improvement in tree and fruit on Wild Goose, of which it is a seedling, which it resembles very much. A much more certain fruiter.

\section{AMERICANA VARIETIES AND HYBRIDS}

All this class flower very late and are sure fruiters.

* MINCO. A hybrid of Miner with Wayland, produced by us in 1896. Tree very vigorous and healthy, resembling Wayland; productive. Fruit nearly as large as the Abundance, bright, shining dark red; ovate, flesh meaty; stone free, small. Ripens with Wayland. Free from rot and curculio. Very valuable.

\section{WAYLAND GROUP OF THE RIVULARIS CLASS}

Bloom late to very late.

WAYLAND. Vigorous; crimson, medium, good, firm; very prolific; sure.

\section{EUROPEAN CLASS}

GIANT. Produced by Luther Burbank; largest of all prunes; very vigorous; purple; fine quality; sure, very late. Best of all prunes among many tried by us.

\section{THE SOUTHERN GROUD OF THE AMERI- CANA CLASS. LATE SOUTHERN PLUMS}

WARD OCTOBER RED. A wild hybrid found in Clay County, Texas, by Robert Ward. Tree very vigorous, spreading; exceedingly hardy in enduring climatic changes; very prolific. It is of a dark, bright red; meaty; of most excellent quality with small stone. Never bothered by rot or curculio. Ripens in Northern Texas in September and October, a month and more after all other varieties are gone, and the latest of all known plums. Exceedingly valuable throughout the South. Entirely distinct in blood from all other plums in cultivation. Price, $\$ 1$ each. 


\title{
BLACKBERRIES
}

Plant 2 feet apart in rows, rows 7 feet,apart, requiring 3,112 plants per acre. Succeed anywhere.

\author{
Read Fuller's Small Fruit Culturist. Price, $\$ 1.50$.
}

\section{PRICES}

The prices following each variety include prepayment if in orders of not less than $\$ 5.00$. If prepayment is not desired, then deduct 15 cents from the dozen rate, 50 cents from the hundred rate and $\$ 2.00$ from the thousand rate.

\section{IN SUCCESSION}

SORSBY MAY. A blackberry larger than Early Harvest and of better quality, and ripens about a week earlier. Very productive and a good shipper; very valuable on account of its extreme earliness. Price, $75 \mathrm{c}$ per $12 ; \$ 3$ per 100.

DALLAS. Very vigorous, drooping, thorny, productive; large, fine. This is proving to be a very valuable market variety. $50 \mathrm{c}$ per $12 ; \$ 2$ per $100 ; \$ 10$ per 1,000 .
ROBISON. Very vigorous, upright, prolific, uniformly very large; of best quality. Sells at the highest market price. Originated by Willard Robison, at Cisco, Texas. It has fruited here for a number of years, and has proven itself one of the most valuable variéties in cultivation. It endures the climatic hardships most excellently. Price, $75 \mathrm{c}$ per $12 ; \$ 2.50$ per $100 ; \$ 12$ per 1,000 .

\section{DEWBERRIES}

MAYES. (Syn. Mayes' Hybrid, Austin's Improved, Austin-Mayes.) This originated at Pilot Point, Texas; we have the genuine. It is exceedingly large, fine and early; prolific. 10c each; 50c per 12 ; $\$ 2.50$ per $100 ; \$ 12$ per 1,000 ; prepaid: or $40 \mathrm{c}$ per 12 ; $\$ 2$ per $100 ; \$ 10$ per 1,000 , not prepaid.

\section{SERVICE BERRY}

SUCCESS. Berry half inch in diameter, dark purple or black, meaty, delicious, borne profusely in clusters. Shrub about three feet high. Much resembles the Blueberry or Huckleberry. Very successful in the South. Ripe in May. Price, 10c each; 75 c per 12 ; $\$ 5$ per 100 , f. o. b.; or $12 \mathrm{c}$ each; $\$ 1$ per $12 ; \$ 6$ per 100 , prepaid.

\section{RASPBERRIES}

Plant 3 feet apart in rows, rows 5 feet apart, requiring 2,994 plants per acre. Need best drouth-resisting soil, on eastern or northern slope.

\section{PRICES}

Packed and on cars at Denison

Packed and prepaid to your depot

\section{BLACK CAPS}

DIXIE. Discovered as a native in Alabama by J. M. Cochran, by whom it was brought to Texas, named and introduced as "hardy as any blackberry vine." The have found this claim to be true by several years' testing. It is the earliest raspberry yet tried by us. It is very prolific, of good medium size.

CUMBERLAND. New, very large, very prolific and very successful here.

KANSAS. A very large, excellent- fruited black-cap; one of the best for a dry, hot climate.

PALMER. This comparatively new variety is considered the largest and best of the early black-caps.

\section{RED VARIETIES}

CARDINAI. Very vigorous and prolific, dark red, very large. Originated in Kansas. Succeeding very well here.

HAYMAKER. New, exceedingly large, bright red, finest quality, enormously productive; succeeding here. 


\section{STRAWBERRIES}

Plant 16 inches apart in rows, rows $3 \frac{1}{2}$ feet apart, requiring 9,000 plants per acre. Deep loamy, sandy soil, with clay subsoil is preferable.

Read Fuller's Strawberry Culturist. Price, 25c.

DRICES_Except Parker Earle, which note

Packed and on cars at Denison_. Per 12

Packed and prepaid to your depot.................... 35

Our plants are not like those handled by many growers-weak, old and mixedbut young vigorous and pure. The very best varieties by actual test for the Southwest. Handled in the very best manner. We test nearly all varieties of any promise as they come out. The following are the cream for this climate.

MICHEL EARLY. Earliest of all; large, vigorous, perfect flower, a fine pollinator for other kinds.

LADY THOMPSON. Large, even size; good color, early and productive; good shipper; fine flavor; strong, healthy; perfect flower.

CRESCENT. Early, prolific; bright; excellent market; pistillate; needs Michel Early to fertilize it.

WOOLVERTON. Uniformly as large as the Bubach, much more prolific and quite early. One of the best varieties tried here.

SPLFNDID. Perfect flower; vigorous and very prolific; large, round, bright red, handsome berry; firm.

BUBACH No. 5. Large, handsome; valuable; very successful here; pistil-

late; needs Splendid or Parker Earle to pollinate it.

* PARKER EARLE. Still leads every other variety in productiveness; plant robust, free from disease, stooling heavily and renewing itself sufficiently by strong runners. It is a model in makeup and endures the extremes in heat and cold remarkably well. Berry regular, uniformly large, conical, with a neck; glossy scarlet crimson; ripens all over; flesh firm, crimson; no hollow core; flowers perfect. Stands at the head as a market and home berry. Price, f. o. b. at Denison, 25c per 12; $75 \mathrm{c}$ per 100 ; $\$ 4$ per 1,000 . Price, prepaid, $40 \mathrm{c}$ per $12 ; \$ 1$ per $100 ; \$ 6$ per 1,000 . We have the best strain.

\section{JAPANESE PERSIMMON}

This remarkable fruit does well all through the South. These are grown from seeds of several of the finest Japan varieties that have all proved hardy and prolific here. Many that we have fruited of these seedlings have always been hardy, large, good and prolific, and give better satisfaction than grafted trees. We have never known a seedling Japan Persimmon fail to bear.

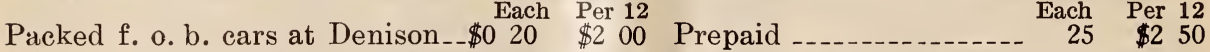

KAWAKAMI. A hybrid of best American and Japanese varieties produced by us. Tree hardy as far north as Illinois. Fruit two to two and one-half inches in diameter, of best quality. A few trees grafted on native persimmon, $\$ 1.00$ each.

\section{SOUTHERN MUSCADINES}

Succeed in deep, rich soil throughout the South; require much trellis room.

Plant 16 feet apart in vineyard rows; prune early after leaves fall.

THOMAS. Very large, black; good wine.

SCUPPERNONG. Large, brownish yellow; good wine.

The above varieties, $15 \mathrm{c}$ each; $\$ 1.50$ per 12 , f. o. b. at Denison; $16 \mathrm{c}$ each; $\$ 1.60$ per 12 , prepaid.

The two varieties following are hybrids of the well-known Scuppernong Grape. They are very vigorous, prolific, excellent in quality and larger in clusters than any of the Muscadine varieties heretofore known. They are absolutely free from rot and mildew, and will succeed anywhere in the Southern States and California. Like the Scuppernong, they require male vine flowering at the same time, growing near, to render them fruitful.

Price, per vine, prepaid, $\$ 1$ each; $\$ 8$ per 12 , f. o. b., or prepaid.

LA SALLE. Very large berry, black; thin skin; tender pulp for this class of grapes; quality equal to or better than Scuppernong. Ripens the earliest of any of this class.

SAN JACINTO. Similar in berry and
MALE MUSCADINES. If planted near the former two renders them very fruitful anywhere in the South. Without such pollinators planted near by they are unfruitful. $25 \mathrm{c}$ each, prepaid. One male vine is sufficient for six or eight bearing vines. cluster to La Salle, the cluster being from two to three times the size of Scuppernong cluster; the quality is still better than La Salle. Ripens one to two weeks later than Scuppernong. Exceedingly prolific. 


$$
19,519.6 \%
$$

\section{WE LEAD ALL COMPETITORS IN THIS FIELD

The Grapes have constantly been the most certain and profitable of any Fruits that we have grown.......

Plant 8 feet apart in rows, rows 9 feet apart; requiring 605 vines per acre.

Read: American Grape Growing and Wine Making, \$1.50. Fuller's Grape Culturist, \$1.50. Weed's Fungi and Fungicides, $\$ 1.00$.

\section{STANDARD LIST-Named in Order of Ripening}

Have a large stock of finest quality. This list contains the best and most successful; have tested all these, with hundreds of others. Flowers perfect, and will bear alone unless otherwise noted; when pistillate, they need a perfect-flowered kind planted near. With irrigation in West Texas and westward all varieties in the list succeed. East of the 100th meridian the Bordeaux mixture spray will enable many varieties to succeed that without it fail on account of rot and mildew. In most regions all varieties do better if treated with Bordeaux spray.

By repeated comparison, it is certainly established that yearling grape vines, as we grow them, outclass No. 1 Northern grown 2-year-olds, and our 2-year-olds are so strong that, if planted early, say from November to February they are capable of bearing, without injury, several clusters the first year. Hence our prices are much cheaper than they appear to be by comparison with others' prices. A weak grape vine is not worth planting at any price.

Unless one-year vines are especially ordered, we will fill all orders with two-year vines if in stock, if no two-year vines of the variety ordered, will send first-class one-year. No difference in price between the two and one-year vines.

\section{PRICES}

Remember that the prepaid prices are for orders of $\$ 5$ or over, and within the states named on page 2 of body of Catalogue, paragraphs 17, 18 and 19.

\section{DESCRIPTION}

MOORE EARLY. Very large, black; good market. Texas

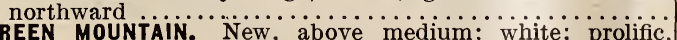
GREEN MOUNTAIN. New, above medium; white; prolific, M'good. Texas northward........ Vine very vigorous and prolific. V.............. sembles the Concord, its grandparent; cluster and berry larger than Concord, firmer, more persistent to cluster....

CAMPBELL EARLY. Is superior in every respect to Concord. and ripens a week earlier. Best production of $\mathbf{G}$. W. Campbell, of Ohio. Ripens evenly, persistent to cluster.. MOORE DIAMOND. One of the finest white American.....

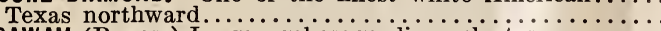
AGAWAM (Rogers) Large, amber; medium cluster..... BRIGHTON. Large, red; fine table, market, wine; pistillate.

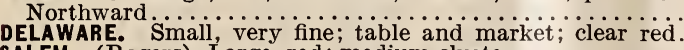
SALEM (Rogers) Large, red; medium cluster.

RED GIANT. A variety produced in Pennsylvania. Cluster. medium, compact; berry immensely large, one to one and one-quarter inches in diameter; color dark red; skin thick and tough; pulp rather tender, sweet and of agreeable flavor, possessing the characteristic of Labrusca muskiness. Vine vigorous, healthy and prolific. Ives or Perkins are good pollinators for it, as it does not pollinate itself.

LINDLEY. Large, red; very good table and market; pistillate

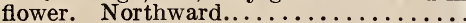

NIAGARA. Large, white; very good table, market; successful

CONCORD. Large, black; table, market; well known. Texas

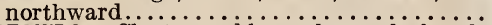

CATAWBA. Cluster and berry large, dark red; juicy, sprightly, fine; fine for market, table and wine.

JEFFERSON. Large, red berry, large cluster; best table,

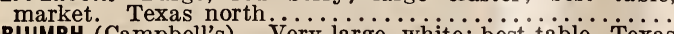
TRIUMPH (Campbell's). Very large, white; best table. Texas to Missouri... W.......

GOETHE. Very large, pink; fine table; North Tex. to Mo. $\ddot{\text { All }}$

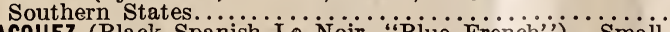

JACQUEZ (Black Spanish Le Noir, "Biue French";). Smail, large cluster, black; red wine. Succeeds well in all South-

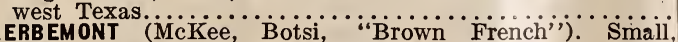
large cluster, purple: finest quality, table, wine; best old

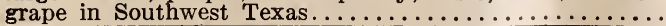

\begin{tabular}{|c|c|c|c|c|c|}
\hline \multicolumn{3}{|c|}{$\begin{array}{c}\text { Packed f. o. b. } \\
\text { Denison }\end{array}$} & \multicolumn{3}{|c|}{$\begin{array}{l}\text { Packed prepaid } \\
\text { to your depot }\end{array}$} \\
\hline Each & Doz & 100 & Each & Doz. & 100 \\
\hline$\$ 010$ & $\$ 075$ & $\$ 500$ & $\$ 010$ & $\$ 085$ & $\$ 600$ \\
\hline 15 & 150 & 1000 & 20 & 175 & 1075 \\
\hline 15 & 150 & $\ldots$ & 20 & 175 & $\ldots \ldots$ \\
\hline 25 & 200 & $\ldots$ & 30 & 225 & $\ldots \ldots$ \\
\hline $\begin{array}{l}10 \\
10\end{array}$ & $\begin{array}{ll} & 75 \\
100\end{array}$ & $\begin{array}{ll}4 & 00 \\
7 & 00\end{array}$ & $\begin{array}{l}12 \\
12\end{array}$ & $\begin{array}{r}85 \\
125\end{array}$ & $\begin{array}{l}475 \\
750\end{array}$ \\
\hline $\begin{array}{l}10 \\
10 \\
10\end{array}$ & $\begin{array}{r}75 \\
75 \\
100\end{array}$ & $\begin{array}{ll}4 & 00 \\
5 & 00 \\
7 & 00\end{array}$ & $\begin{array}{l}12 \\
12 \\
12\end{array}$ & $\begin{array}{r}85 \\
85 \\
1 \quad 25\end{array}$ & $\begin{array}{ll}4 & 75 \\
5 & 50 \\
7 & 50\end{array}$ \\
\hline 50 & 400 & 3000 & 50 & 415 & 3100 \\
\hline $\begin{array}{l}10 \\
10\end{array}$ & $\begin{array}{l}75 \\
75\end{array}$ & $\begin{array}{ll}4 & 00 \\
5 & 00\end{array}$ & $\begin{array}{l}12 \\
12\end{array}$ & $\begin{array}{l}85 \\
85\end{array}$ & $\begin{array}{ll}4 & 75 \\
6 & 00\end{array}$ \\
\hline 10 & 75 & 300 & 12 & 85 & 375 \\
\hline 10 & 75 & 400 & 12 & 85 & 475 \\
\hline 10 & 100 & 800 & 12 & 110 & 875 \\
\hline $\begin{array}{l}10 \\
10\end{array}$ & $\begin{array}{ll}100 \\
75\end{array}$ & $\begin{array}{ll}8 & 00 \\
4 & 00\end{array}$ & $\begin{array}{l}12 \\
12\end{array}$ & 110 & $\begin{array}{ll}8 & 75 \\
4 & 75\end{array}$ \\
\hline 10 & 100 & 600 & 12 & 110 & 675 \\
\hline 10 & 100 & 600 & 12 & 110 & 675 \\
\hline 10 & 100 & 600 & 12 & $\begin{array}{ll}1 & 10\end{array}$ & 675 \\
\hline
\end{tabular}




\section{THE CREAM OF THE MUNSON GRAPES}

\section{THE BEST THIRTY-NINE SELECTED OUT OF SEVENTY-FIVE THOUSAND VARIETIES PRODUCED BY T. V. MUNSON IN TWENTY-FIVE YEARS}

In the following list the varieties are named in their alphabetical order, and not in the order of ripening, as in the Standard List; howerer, the time of ripening is stated with each variety, and in comparison with other well-known varieties. All the varieties in this list will be found on page 19 at end of descriptions named in the order of ripening.

As these varieties become more and more extensively planted, cultivated and tested throughout the country, their great value becomes more apparent and better known, and nothing but praise is given them, and they are now rapidly taking the place of the better old varieties. With these varieties we have held the field in market against all comers while the old standard varieties were in season, and we have had the field entirely to ourselves with the later varieties after the standard varieties were all gonetwo months or more here.

All the varieties possessing Post Oak blood, in order to get best results in cropping, should be treated the same as Herbemont, that is, plant wide apart, as much as twelve to sixteen feet in the rows. and have long arm pruning. They do especially well upon the Munson Canopy Trellis, mentioned in Husmann's American Grape Growing, page 64. Distance apart to plant and kind of pruning required for best results are mentioned with each variety.

\section{PRICES}

Remember that the prepaid prices are for orders of $\$ 5$ or over, and within the states named on page 2 of body of Catalogue, paragraphs 17, 18 and 19.

\begin{tabular}{|c|c|c|c|c|c|c|}
\hline \multirow{2}{*}{$\begin{array}{c}\text { VARIE'TIES } \\
\text { (Described on pages } 15 \text { to } 23 \text { ) }\end{array}$} & \multicolumn{3}{|c|}{$\begin{array}{l}\text { Packed f. o. b. } \\
\text { Denison }\end{array}$} & \multicolumn{3}{|c|}{$\begin{array}{l}\text { Packed prepaid } \\
\text { to your depot }\end{array}$} \\
\hline & Each & Doz. & 100 & Each & Doz. & 100 \\
\hline 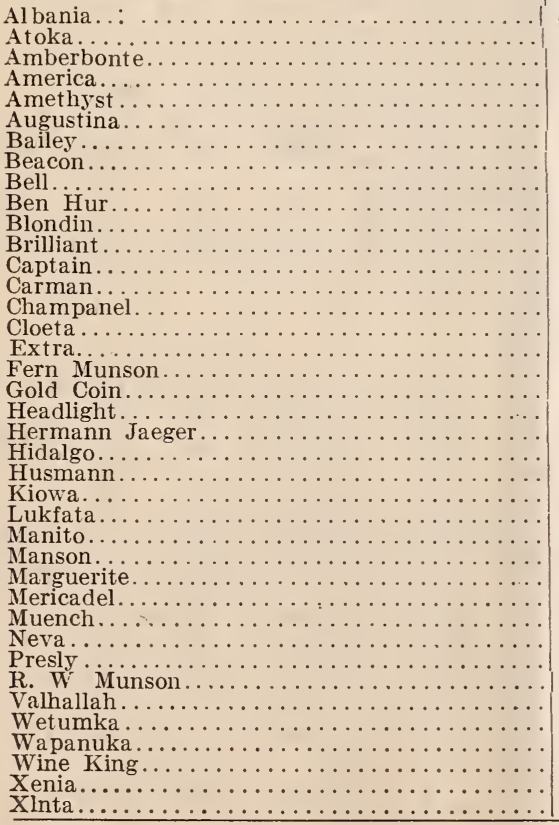 & 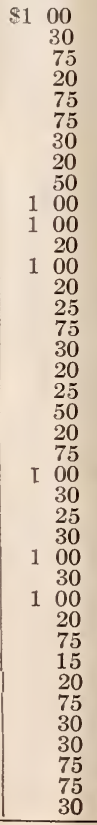 & $\begin{array}{rr}\$ 8 & 00 \\
3 & 00 \\
6 & 00 \\
1 & 00 \\
6 & 00 \\
6 & 00 \\
3 & 25 \\
1 & 50 \\
4 & 00 \\
9 & 00 \\
8 & 00 \\
1 & 25 \\
12 & 00 \\
1 & 25 \\
2 & 00 \\
6 & 00 \\
3 & 25 \\
1 & 50 \\
2 & 50 \\
4 & 00 \\
1 & 50 \\
6 & 00 \\
12 & 00 \\
3 & 00 \\
2 & 00 \\
3 & 00 \\
8 & 00 \\
3 & 00 \\
8 & 00 \\
1 & 50 \\
6 & 00 \\
1 & 00 \\
1 & 50 \\
6 & 00 \\
3 & 25 \\
3 & 25 \\
6 & 00 \\
6 & 00 \\
3 & 00 \\
\end{array}$ & 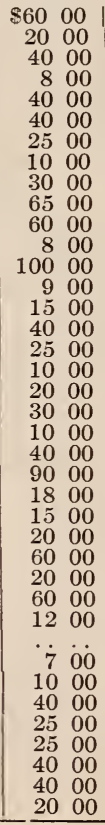 & $\begin{array}{rr}\$ 1 & 00 \\
& 35 \\
& 75 \\
& 25 \\
& 75 \\
& 75 \\
& 35 \\
& 35 \\
& 25 \\
& 50 \\
1 & 00 \\
1 & 00 \\
& 25 \\
1 & 00 \\
& 25 \\
& 30 \\
& 75 \\
& 35 \\
& 25 \\
& 30 \\
& 50 \\
& 25 \\
& 75 \\
1 & 00 \\
& 35 \\
& 30 \\
& 35 \\
1 & 00 \\
& 35 \\
1 & 00 \\
& 25 \\
& 75 \\
& 20 \\
& 25 \\
& 75 \\
& 75 \\
& 35 \\
& 35 \\
& 75 \\
& 75 \\
& 35 \\
\end{array}$ & $\begin{array}{rr}\$ 8 & 00 \\
3 & 25 \\
6 & 00 \\
1 & 25 \\
6 & 00 \\
6 & 00 \\
3 & 50 \\
1 & 75 \\
4 & 00 \\
9 & 00 \\
8 & 00 \\
1 & 50 \\
12 & 00 \\
1 & 50 \\
2 & 25 \\
6 & 00 \\
3 & 50 \\
1 & 75 \\
2 & 75 \\
4 & 25 \\
1 & 75 \\
6 & 00 \\
12 & 00 \\
3 & 25 \\
2 & 25 \\
3 & 25 \\
8 & 00 \\
3 & 25 \\
8 & 00 \\
1 & 75 \\
6 & 00 \\
1 & 25 \\
1 & 75 \\
6 & 00 \\
3 & 50 \\
3 & 50 \\
6 & 00 \\
6 & 00 \\
3 & 25 \\
\end{array}$ & $\begin{array}{rl}\$ 60 & 00 \\
21 & 00 \\
40 & 00 \\
9 & 00 \\
40 & 00 \\
40 & 00 \\
26 & 00 \\
11 & 00 \\
30 & 00 \\
65 & 00 \\
60 & 00 \\
9 & 00 \\
100 & 00 \\
10 & 00 \\
16 & 00 \\
40 & 00 \\
26 & 00 \\
11 & 00 \\
21 & 00 \\
31 & 00 \\
11 & 00 \\
40 & 00 \\
90 & 00 \\
19 & 00 \\
16 & 00 \\
21 & 00 \\
60 & 00 \\
21 & 00 \\
60 & 00 \\
13 & 00 \\
8 & 00 \\
8 & 00 \\
11 & 00 \\
40 & 00 \\
26 & 00 \\
26 & 00 \\
40 & 00 \\
40 & 00 \\
21 & 00 \\
\end{array}$ \\
\hline
\end{tabular}




\section{DESCRIPTIONS_Sec prices on page 14}

ALBANIA. Parentage.-Post Oak $x$ Norton $\mathrm{x}$ Herbemont. Cluster large to very large, shouldered; berry medium, translucent white; skin thin and tough; pulp very tender and juicy, sprightly, with Herbemont character, but sweeter; very vigorous and prolific; uses, late market, table and white wine. Late ripening with Fern, will remain on until frost; the latest white grape in cultivation.

ATOKA. (America $x$ Delaware). Growth vigorous. Clusters large, slightly conical to nearly cylindrical, often with short shoulder, fairly compact. Berries persistent, small to medium, globular, dark purplish red, with little bloom; skin thin and sufficiently tough never cracks; pulp juicy, tender, very sprightly and agreeable when ripened, easily freeing the seeds; rich both in sugar and in acid; quality pure and fine, sells readily in the market, and gives satisfaction. Resists disease and climatic changes excellently. Adapted South and North. 10 to 12 feet apart. Long arm pruning.

AMERBONTE. Hybrid of America with Herbemont. Cluster very large; berry small to medium, larger than Herbemont; color clear, dark red, beautiful; thin, tough skin; tender, melting pulp, juicy and fine quality; vigorous and prolific. Far more resistant to diseases than Herbemont. Ripe with Herbemont. A much more valuable grape. Hardy as far north as St. Louis. 12 to 14 feet apart.

AMERICA. (Seedling of Jaeger, No. 70.) Growth very strong. Cluster conical, sufficiently compact. Berries very persistent, medium size, globular, black with little bloom, and scatteringly dotted jet black with white speck in center of dots; skin thin and tender, but does not crack; pulp melting, juicy, easily freeing the slender seeds; when fully ripe very rich in sugar; also rich in agreeable acid; possesses a very distinct peculiar flavor, much liked by some; not "foxy," making a good combination market and wine grape. A very good port wine has been made from it without "fortifying." Ripens at Denison, Texas, July 20 th to August 1st, a little after Concord, and always evenly. Very prolific with long arm pruning and when pollenized by other varieties, as it does not thoroughly pollenize itself. Beacon is a good mate. Endures the severest drouth with ease. Has passed through 27 degrees below zero without damage. Not attacked by mildew, rot or leaf folder, and has given excellent results in Cal- ifornia as a resistant graft stock for Vinifera varieties. Adapted South and North. Plant 12 to 14 feet apart.

AMETHYST. Parentage-Delago $x$ Brilliant. Cluster medium; berry large, clear red, with delicate bloom; skin thin and tough; pulp tender, quality the best. Uses, market, table, white wine. Medium season, with Concord. Plant 8 feet apart, short arm. Requires spraying.

AUGUSTINA. Combination of Delaware, Goethe, Brilliant. Cluster large; berry very large, translucent carmine red, very handsome; skin thin and tough; pulp meaty, tender and juicy, quality the best, with very delicious characteristic flavor. Good grower, very prolific. Table, market, white wine. Season very late, after Catawba. Plant 8 feet, short arm pruning. Spray.

BAILEY. (Big Berry Post-Oak x Triumph.) Growth strong. Clusters large to very large, cylindrical or often branching, generally compact. Berries persistent, large, black, with little bloom; skin thin and tough, never cracking; pulp meaty, but not tough, juicy, sprightly, of pure very good quality, considerably above Concord; seeds readily parting from pulp. Ripe July 10 to 30 . A valuable market grape, easily superseding Concord, especially in South-Central and Southwest Texas, where it has done remarkably well. Plant 10 to 12 feet apart; medium to long pruning.

BEACON. (Big Berry Post-Oak $x$ Concord.) Growth medium in South Texas, becoming stronger in North Texas to very strong in Missouri. Very prolific, of large cylindrical clusters, often shouldered, moderately compact. Berries as large or larger than Concord, black, with rather heavy white bloom, hang to cluster about equally well with Concord, but not so well as Bailey; skin a little tougher than Concord, never cracks; pulp rather more tender than Concord, very juicy, sprightly and of a very similar flavor to Concord, rather more agreeable; seeds readily leave the pulp. Ripe here July 15 to 25 . The vines have continuously borne very heavily and endured the climatic hardships well in Texas and in Missouri and Illinois, passing 27 degrees below zero at Palmyra, Missouri, in the grounds of Dr. Jaudon, and bore heavily the following season. Adapted South and North. Dr. B. A. Jaudon says that Beacon and Fern are the best two 


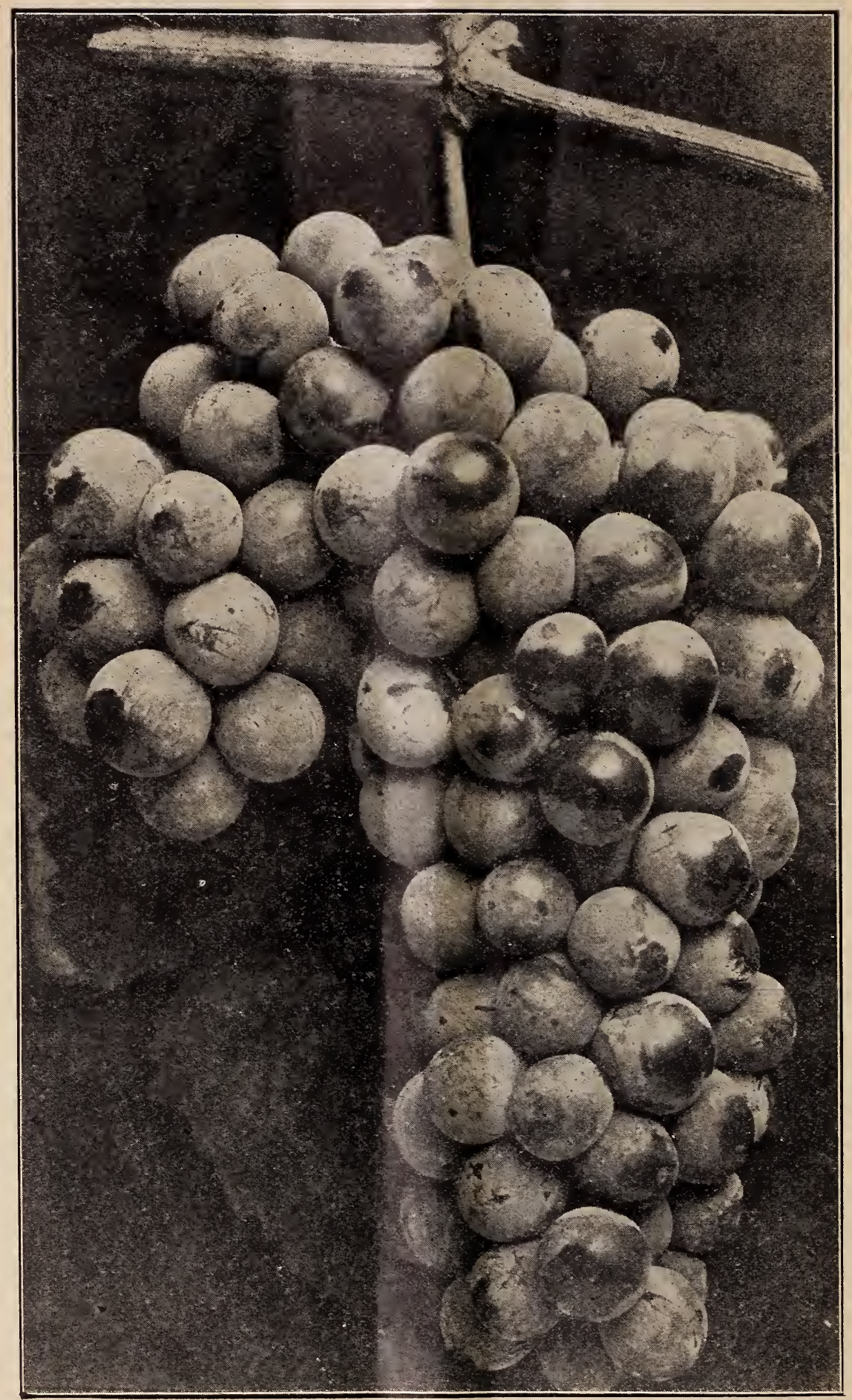


grapes in cultivation for his region, near Quincy, Ill. Plant 8 to 10 feet apart.

BELL. A hybrid of Elvira with Delaware. Vine vigorous, healthy, free from mildew and leaf-folder, very hardy, a good, sure producer; cluster medium, cylindrical, often with a shoulder, fairly compact; berry medium, round, greenish yellow, rarely attacked with black rot; skin thin, sufficiently tough to prevent cracking under ordinary weather changes; pulp rather tender, juicy, very sweet and agreeably flavored; ripens just before Concord. We consider it a superior Grape to the Green Mountain. Successful in Texas northward. Have received very flattering testimonials of this grape.

BEN HUR. Parentage a combination of Post Oak grape with Norton and Herbemont. Vine very vigorous, very prolific, free from rot and mildew; cluster large; berry little under medium, black, persistent; pulp very vender, juicy, sprightly, sweet. We consider this one of the most valuable of American wine grapes. Those who like the Le Noir grape will like this, as it has all the good qualities of the Le Noir without its tendency to rot or mildew. Medium to long arm pruning. 10 feet apart.

BLONDIN. Combination of TenDollar-Prize-Post-Oak, Norton Virginia and Herbemont. Cluster large, compact, shouldered; berry medium, white translucent; skin very thin and tough; pulp very tender, juicy, sprightly, quality excellent, nearly best. Very vigorous, prolific. Late, with Triumph and Catawba in season. Very valuable as a late market and white wine grape. 10 feet, medium pruning.

BRILLIANT. (Lindley $\mathrm{x}$ Delaware.) Growth strong. Vine endures winters anywhere up to 15 degrees below zero. Endures Texas climate well. Clusters large, cylindrical, or somewhat conical, often shouldered, open to compact. Berries large, globular, light to dark red, translucent, with a thin bloom, very handsome when well ripened; skin thin, rather tender, but seldom cracks; pulp meaty, yet very tender, melting and delicious, usually preferred for table and eating fresh to Delaware, with which it outsells 5 to 10 cents per eight-pound basket in the markets where it is known. Seeds readily part from the pulp. Ripens just before the Delaware and yields on an average fully twice as much. It ships about equally well or better than Concord. Its foliage is less attacked by mildew than
Delaware, and spraying with Bordeaux mixture will entirely prevent this. Endures heat and drouth fairly well, much better than Concord. Making a fine record in Georgia, as well as in Texas. Adapted South and North. Fine reports of it from New York. 8 feet, short arm pruning.

CAPTAIN. Parentage - America crossed with R. W. Munson. See description of these. Cluster very large; long cylindrical, reaching ten to twelve inches; berry large, black, with white bloom; skin thin; ships well; pulp tender, freeing seeds easily, quality nearly best, much better than Concord. Exceedingly vigorous and prolific. Uses, market, table, red wine. Medium season. 10 to 12 feet, medium pruning.

CARMAN. (Post-Oak No. $1 \times$ Triumph.) Growth vigorous; foliage never attacked by leaf-folder or mildew; very prolific. Cluster large to very large, have reached two pounds in rare instances, shouldered or branched, conical, very compact. Berries persistent, medium, globular, black with thin bloom; skin thin and tough, never cracking; pulp meaty, firm, yet tender when fully ripe, of pure, rich quality, much superior to Concord; seeds easily leaving the pulp. Vines now 18 years old, have borne 15 heavy crops, show no signs of decline. Has always been one of the most profitable varieties with us and greatly praised in many sections of the South as far north as 40 degrees latitude. Ripe one to three weeks after Concord is gone. Will hang on the vines many days after becoming ripe without deteriorating. Plant 10 to 12 feet apart. Medium pruning.

CHAMPANEL. ( $\mathrm{V}$. Champini $\mathrm{x}$ Worden.) Growth rampant, exceedingly resistant to heat and drouth, growing well in limy black soils. Clusters large, conical, with long peduncle, rather open. Berries globular, large, black, with white bloom, persistent; skin thin, tough; pulp tender, juicy, very sprightly, acid unless well ripened, then quite agreeable; seeds rather large, easily leaving the pulp. Ripe about with Concord, which it resembles very much in cluster and berry. Does well in any soil, but valuable for black waxy lands of the South, where few other varieties will grow. Ripens evenly and not given to cracking or dropping as is the Concord or Worden in the South. 10 to 12 feet. Long arm pruning.

CLOETA. Probably the best of all American black grapes. ParentageAmerica $x$ R. W. Munson. Cluster large, berry large, black, handsome; 


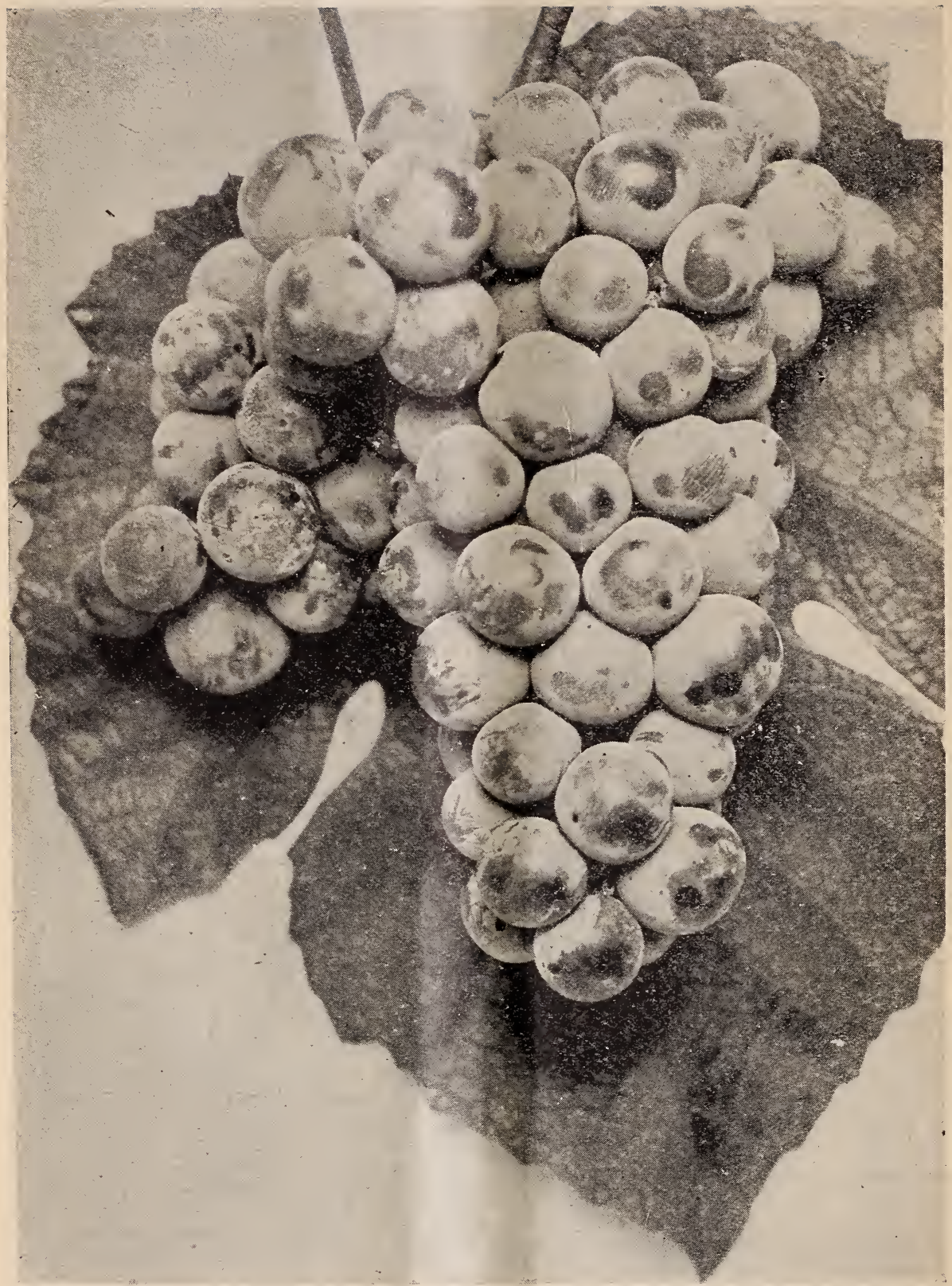

HEADLIGHT-See page 19

First variety of grapes to be exhibited from Texas at World's Fair, St. Louis, 1904. Exhibit made June 26, 1904. 
skin thin, handles well; pulp tender, juicy, sprightly, far better quality than Concord. Vine very vigorous and prolific. Uses, market, table, red wine. Medium late, just after Concord. 10 to 14 feet, long pruning. Requires hot, dry weather to acquire high quality.

EXTRA. (Big Berry Post-Oak x Triumph.) Growth strong; cluster oblong to cylindrical, sometimes shouldered, moderately compact. Berries persistent, globular, medium to large, dark purple to black, with moderate bloom; skin thin, tough, never cracks; pulp tender, juicy, sprightly, agreeable, sweet; seeds easily parting from the pulp. Ripe July 25 to August 10 . Does well in South Texas. An excellent market and wine grape. Mr. William Pfeffer of Santa Clara county, California, a winemaker of reputation, writes in the "Pacific T'ree and Vine:",

"The Post Oak family of hybrids are most vigorous, good bearers, the best resistants, and make very fine wines. In fact, there is no Zinfandel, Mataro or Carignan wines, not to name a long list of standards, that can equal a wine of Neva or of Big Extra, and no light claret as refreshing as one of Elvicand."

FERN MUNSON. (Post-Oak No. $1 \mathrm{x}$ Catawba.) Growth very strong. Cluster medium to large with long peduncles. Berries globular, medium to large, very persistent; very dark purplish red to nearly black; skin thin, tough; pulp firm, but not tough; very juicy, sprightly, with very agreeable Catawba flavor when fully ripe; seeds leave the pulp readily. Ripens very late in August or early in September, and hangs on until frost if desired, becoming excellent in quality and giving full satisfaction in market. Very profitable, as it ripens when all old varieties are gone. Free from black rot. Has endured 27 degrees below zero and has borne well the following season. It endures drouth excellently. Adapted for the South and North to latitude 40 degrees. 10 to 14 feet, long pruning.

GOLD COIN. (Norton $\mathrm{x}$ Martha.) Growth medium. Clusters medium or above, ovate shouldered, proper degree of compactness. Always sets a crop of well-filled clusters; peduncle medium to long. Berries large, globular, yellowish when fully ripe, persistent; skin thin, tough, never cracks, and rarely attacked by rot; pulp about same consistency as Concord, very juicy and exceedingly sweet; retains a little of the Martha flavor; liked by most persons. Very handsome in the basket and markets excellently; has always been very profitable. Ripens with Catawba, endures all extremes of climate well. Favorable reports of it from all parts of the South, and as far North as 40 degrees latitude. 8 to 10 feet. Medium arms.

HEADLIGHT. This remarkable variety, produced in 1895 , is a combination of Delaware and Lindley. The cut is from a photograph, exact lifesize, of a cluster which had remained on the vines through July, a month after it was fully ripe, and shows the size, form of cluster and berry and the remarkable keeping qualities of this variety. The berry is very persistent to the cluster, clear, translucent red, covered with a thin white bloom, and is very handsome. The skin is thin and tough, the pulp tender, melting and juicy, sprightly highly flavored, very sweet, of the very best quality; seeds few; vine vigorous, healthy, prolific; the foliage is but little attacked by mildew, the fruit rarely ever attacked by rot. It will outyield and outsell Delaware by a large per cent, and is the earliest grape known to us. As a money-making market and table grape we consider this the most valuable among very early varieties that has ever been produced. 8 feet. Short arm pruning.

HERMANN JAEGER. (Post-Oak No. $1 \mathrm{x}$ Herbemont.) Growth very strong, endures the Texas climate well. Clusters large to very large, shouldered, conical, very compact; peduncle short. Berries small to medium, black, persistent; skin thin, tough, does not crack; pulp tender, very juicy, easily freeing the seeds. Quality better than Concord. A profitable market and table grape. Ripens a week later than Concord. Not attacked to any extent by mildew, rot or leaf-folder. Valuable in Southwest Texas especially, and successful throughout the South. 10 to 12 feet, long arm.

HIDALGO. A combination of Delaware, Goethe and Lindley. Cluster large; berry large, yellowish white; skin thin and tough; pulp tender and melting, quality best; uses, table, market, white wine. Early, handsome, delicious. 8 feet, short arm pruning.

HUSMANN. (Armlong $x$ Perry.) Combination of $\$ 10$ Prize and No. 2 Fost-Oak grapes, with Black Eagle and Herbemont. Growth vigorous, endures Texas climate well. Clusters very large, long, cylindrical, sometimes shouldered, on medium peduncles, compact. Berries medium size, globular, black, persistent; skin thin, delicate, yet tough; pulp 


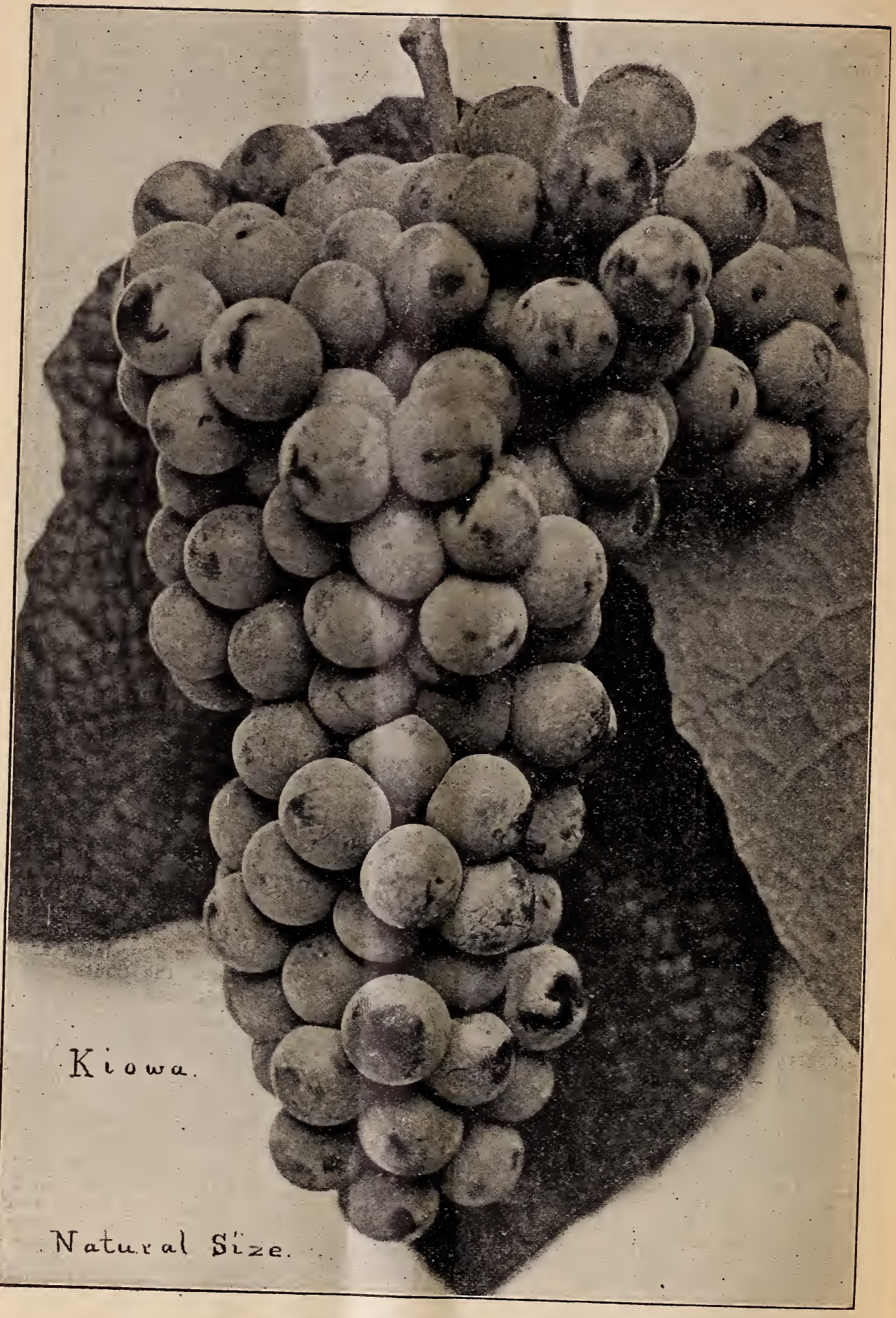

KIOWA-See page 21 
melting, very juicy, sprightly, of high, pure flavor. More satisfactory by far as a market and table grape than Herbemont, and excellent for red wine. Very prolific, even on short arms. Ripens with Herbemont and belongs to same range of country. 10 feet.

KIOWA. (Jaeger $43 \times$ Herbemont.) Growth very strong and healthy. Cluster large, cylindrical, shouldered, and sometimes branched; peduncle of medium length. Berries small to medium, a good size larger than the Herbemont; juice red. Rarely touched by rot. A good market and an excellent wine grape. Ripens after Herbemont a week. Requires wide planting and long pruning, 12 to 14 feet. Adapted for the South.

LUKFATA. ( $\mathrm{V}$. Champini $\mathrm{x}$ Moore Early.) Growth strong. Endures heat, drouth and cold remarkably well. Succeeds in black, limy soils. Not injured by mildew. Cluster medium, ovate, sometimes shouldered, compact; berries globular, large, persistent; does not crack; pulp about same as Moore Early, more juicy and very sweet and agreeable. Ripens early and evenly. Sells in the market as well or better than Concord, and ships far better. Little attacked by rot. A good market and a fair table grape. Flowers have reflexed stamens, hence it must be grown near some variety with erect stamens flowering at same time, such as Ives; then it bears well. Plant 10 to 12 feet apart. Give long pruning.

MANITO. (America $\mathbf{x}$ Brilliant.) Growth very similar to America, endures extremes of climate very well. Clusters long cylindrical, rather open, with long peduncle; flowers perfect, bears well alone, very prolific; berries medium, globular, persistent, dark purple, with white specks; very distinct and unique in appearance; skin thin and tough; pulp very tender, juicy, sweet and agreeable, parting from the seeds with ease. Ripens very early, about with Moore Early, packs beautifully and ships excellently. A. very profitable market grape, also a good wine grape. Adapted for general North and South. 8 to 10 feet, medium arms.

MANSON. An exceedingly valuable white grape. A hybrid of R. W. Mun son with Gold Coin, produced in 1899 Vigorous and productive; clusters large, berry above medium, of yellow color; skin thin and tough; pulp tender, quality excellent. Ripens late, with Triumph.

MARGUERITE. (Post-Oak No. $2 \mathrm{x}$ Herbemont.) Growth very strong, not attacked by mildew, endures Texas elimate perfectly. Clusters medium, cylindrical, shouldered with short peduncle, compact. Berries a good size larger than Herbemont, globular, dark purple, persistent; skin thin and tough, never cracks; pulp tender, juicy, sprightly, about equal to Herbemont. Ripens some three weeks later than Herbemont, and hangs on through October and sells well in the market. It makes a fine white wine. A shy bearer on short arm pruning, but on long arms it bears heavily. Succeeds everywhere in the South. A splendid arbor grape. 14 to 16 feet.

MERICADEL. A hybrid of America with Delaware, produced in 1898. Vine very vigorous and very productive; cluster large, berry medium, purple, very persistent to cluster; skin thin and tough; pulp tender and meaty, of very best quality; fine for table and market. Ripens late, just after Concord. Doing finely in Florida and Southeastern part of United States. Pronounced of the best quality by many who have taken part in our "grape-tasting parties." Plant 8 feet apart, medium arms in pruning.

MUENCH. A hybrid of Neosho (a Missouri Post-Oak grape found by $H$. Jaeger) and Herbemont. Vine very vigorous and free from all diseases; cluster large to very large; berries above medium, purplish black; pulp very tender and meaty, of fine quality. Sells readily in the market, also fine for table. Well adapted to the South. Ripens very late, after Herbemont. Plant 10 feet, long arm pruning.

NEVA. (Neosho, a variety of PostOak of Southwestern Missouri, crossed with Herbemont.) Vine vigorous, healthy and productive. Cluster long and very showy. Bery small to medium; color dark purple. A most excellent wine grape, as testified by expert wine growers. Ripens very late. Plant 12 feet, long arm.

PRESLY. (Elvira $x$ Champion.) Growth medium, resists mildew and rot well; clusters ovate, shouldered, compact, with short peduncle; berries small to medium, a shade larger than Delaware, slightly ovate, moderately persistent, at first light red, becoming dark when fully ripe, handsome as Delaware when packed in baskets; skin thin, tough, does not crack; pulp tender, moderately juicy, fair quality, much better than Champion. Ripe with or before Champion, and a profitable first early market grape. Endures the cli- 


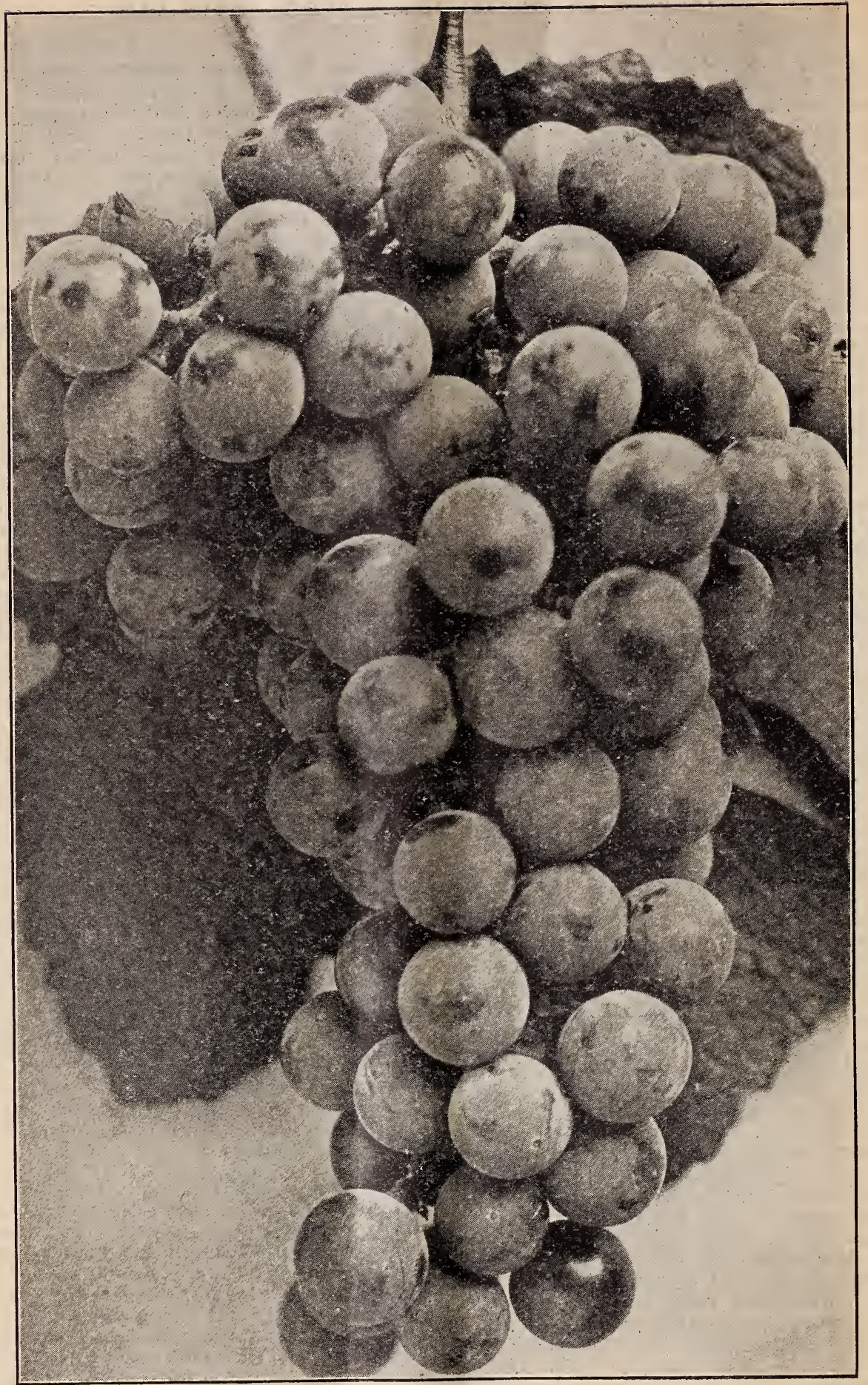

R. W. MUNSON-See page 23

Combination of Texas Post-Oak Grape with Concord and Muscat. Ripens just before Concord, and of much better quality. Black. 
mate better than Ives, but belongs further north to be fully at home. 8 feet, short arm pruning.

ROMMEL. (Elvira and Triumph.) Owing to the fact that Wapanucka and Rommel being of same appearance and season, but Wapanuka being of better quality than Rommel (which is saying a great deal, as the Rommel is of extra fine quality), we have discontinued growing the Rommel in favor of the Wapanuka, as we do not wish to carry several varieties where one will serve the same purpose. See Wapanuka.

R. W. MUNSON. (Big Berry PostOak x Triumph.) Growth strong. Clusters medium to large, cylindrical, often shouldered, peduncle medium. Berries, when well grown, medium to large, globular, persistent, black without bloom; skin never cracks; pulp tender, juicy and of a very good quality, better than Concord or Beacon. Ripe just before Concord. Gives good satisfaction on market. Bears heavily on long pruning and when pollinated by other erect-stammened varieties flowering at same time, its own pollen not being fuliy adequate, although its flowers are perfect. Concord and Brilliant good pollinators for it. Ships well. 10 to 12 feet apart. A. M. Bowman of Salem, Va., after fruiting this variety, pronounces it the best American grape in vine and fruit.

VALHALLAH. A hybrid of Elvicand and Brilliant; that is, one-fourth Mustang, one-fourth Elvira, one-fourth Lindley and one-fourth Delaware. A very vigorous drouth-enduring, prolific vine, well suited for black lands and will endure Missouri winters. Cluster medium; berry large, bright clear red; thin, tough sliin; tender, juicy pulp of quality nearly equaling Brilliant. Hangs on perfectly; never cracks or rots. Ripens about with voncord. to 10 feet. Medium pruning.

WFTUMKA. (Elvira $x$ Herbemont x Gold Coin.) Growth medium, healthy, withstands mildew and rot well. Clusters medium to large, ovate, sometimes shouldered; peduncle medium. Berries large, globular, persistent, yellowish green; skin never cracks; pulp juicy; tender, freeing the seeds easily; quality better than Niagara. Ripe late after Concord is off. Bears heavily on short arms. A profitable market and table grape and will make an excellent white wine. 8 feet: Adapted for the South, and same range of Gold Coin.

WAPANUKA. (Rommel x Brilliant.) Growth medium to strong, equal with Concord, less attacked by mildew than
Brilliant. Cluster medium to large, cylindrical, shouldered, properly compact; peduncle short to medium. Berries large, five-eighths to seven-eighths inch in diameter, globular, persistent, rich yellowish white translucent; skin very thin and delicate, yet seldom cracks, and handles better than Rommel. Ripe about with Delaware. Far superior to Niagara and Green Mountain. For nearby market and table grape there is no other variety superior, if equal, to it. Very prolific, requires short pruning. Succeeds well North and South. Undoubtedly one of the best, if not the best, table and eating grape produced in the United States. Takes the place of the Rommel, it being superior to it, although the Rommel is near the top for extra fine quality and flavor. Plant 8 feet.

WINE IKING. A hybrid of Winona and America. Winona is a pure seedling of Norton Virginia, and quite an improvement on that celebrated variety, hence Wine King is a thoroughbred pure American blood of the finest wine properties and large enough in berry and cluster to make a good market grape. It has been sold in the market and gives excellent satisfaction. Produced in 1898. Cluster large, berry medium, black, very persistent. Skin thin, never cracks; pulp tender and juicy, rich and sprightly, intensely red juice. Seeds small. Very vigorous, prolific; free from all diseases. Will succeed from the Gulf to Michigan. Ripens just before Norton Virginia. Supersedes Hopkins and Norton Virginia. 10 to 12 feet, long arm.

XENIA. Parentage-Delaware, Goethe and Triumph. Clusters medium, compact, very large, white; skin thin and tough; pulp meaty, tender, sprightly, highly flavored, best. Good grower, prolific. Very late, with Fern or just before. 8 feet, short arm. See cut, back cover page.

XLNTA. (America x R. W. Munson.) Growth strong. Clusters large, cylindrical, shouldered with medium peduncle, fairly compact, unless not well pollenized, then loose; flowers have reflex stamens and perfect-flowering kinds should be planted near, such as Brilliant, Delaware or Gold Coin. Berries medium to large, globular, persistent, black, with little bloom; skin thin, never cracks; pulp meaty, tender and of a very agreeable, sprightly quality. Ripe with or later than Concord. Very prolific on medium to long pruning; an excellent market and wine grape. Endures climatic extremes well. 10 feet. Adapted throughout the South and North to the Ohio river. 


\title{
ORDER OF RIPENING OF THE MUNSON GRADES
}

\author{
DESCRIBED ON PAGES 15 TO 23
}

This arrangement is given to aid customers in making selections.

The dates given are for Red River region of North Texas, Northern Alabama and South Carolina. June 25th to July 1st, as early or earlier than Champion: Headlight, Presly.

July 5th to 10th, about with Moore Early: Manito, Brilliant, Wapanuka, Lukfata, Hidalgo.

July 10th to 15th, about with Ives and Delaware: R. W. Munson, Bell, Beacon. Cloeta, Captain. July 15th to 25th, about with Concord: Champanel, Amethyst, Mericadel, Hermann Jaeger, Valhallah, Extra.

July 25th to August 5th, about with Triumph and Catawba: Carman, America, Bailey, Xlnta, Atoka, Manson, Wetumka, Gold Coin, Blondin, Wine King, Augustina.

August 5th to 15th, about with Herbemont: Xenia, Husmann, Kiowa, Amerbonte, Muench, Ben Hur. August 15th to September 1st, later than any old varieties: Albania.

In September, hanging until October: Fern and Marguerite, Neva.

\section{EUROPEAN (VINIFERA) VARIETIES}

Plant 8 feet apart in rows, with rows 9 feet apart, requiring 605 vines per acre.

Read Fungi and Fungicides, $\$ 1.00$.

\section{PRICES}

Each
Packed on cars at Denison $\quad \begin{array}{rrr}\text { Per } 12 & \text { Per } 100 \\ \text { Packed and prepaid to your depot. } & \$ 100 & \$ 700 \\ \end{array}$

Prepaid prices are for orders of not less than $\$ 5.00$, and to the places named in paragraph 17 , page 2 , which please read fully.

These succeed in far South and West Texas, especially with irrigation, equally as well as in California but fail entirely in Central and East Texas, owing to phylloxera, rot, mildew, etc.; but by grafting on resistant roots and spraying with Bordeaux mixture, succeed in all but extreme North Texas, and with winter protection can be fruited there.

We have in our vineyard, on sandy soil, the following list, growing and fruiting successfully, selected from among a large number of the finest French, Spanish, Hungarian, Italian. Sicilian and Persian varieties. Some are of recent importation. We have no grafted vines for sale, but can supply cuttings of the best resistant stocks for the South and California by mail at $\$ 2$ per 100 . We also offer rooted graft stocks, which see page 25 .

CALABRIAN. (Italian.) of muscat type; vigorous, healthy; cluster very large, compound; berry large, roundish, yellowish, meaty, juicy, fine; table, market, raisin.

FEHER SZAGOS. (Hungarian.) Very vigorous, healthy; Persian type; cluster very large; berry cylindrical, eilipsoidal, curved like Cornichon; white, meaty, very fine; table, market, raisin.

GRIESA (DE PIEMONTE). (Italian.) Vigorous, healthy; cluster very large, compound; berry large, purplish black, meaty, juicy, very fine; table, market, white wine.

MALAGA. (Spanish.) Vigorous and healthy; cluster very large; berry large, meaty, ovate, white; table, market, raisin.

PERLE OF ANVERS. Large compound clusters; very large yellowish white berries of highest quality. Late.

QUAGLIANO. (Sicilian.) Vigorous;

prolific; cluster large; berry large, round, grayish purple, meaty, juicy, fine, late; table, market.

RED CORNICHON. Large cluster; large red berry. Very showy; one of the California standard market sort.

SAUVIGNON JAUNE. (French.) Vigorous, healthy; cluster large, compact; berry medium, yellow, meaty, tender, early; table, white wine.

SWEETWATER. Very early; large cluster; medium berry, beautiful pearly yellowish white. Very prolific. of good quality.

VERDELHO. (French.) Vigorous, healthy; cluster large; berry large, ovate, yellowish, meaty, juicy; table, market.

VIOLET CHASSELAS. (French.) Vigorous; cluster large; berry large, ovate, violet, beautiful, superb qaulity; table, market, wine. 


\section{RESISTANT GRAFT STOCKS FOR GRADES}

To meet the demand of some of our customers for good Stocks, resistant to phylloxera, on which to graft more delicate varieties of Grapes, especially the Viniferas, which thereby can be made very successful in many parts of the South. especially in Southwestern Texas, we have grown a small stock of the most approved well-tested species and varieties, which we offer at the following prices:

\section{PRICES}

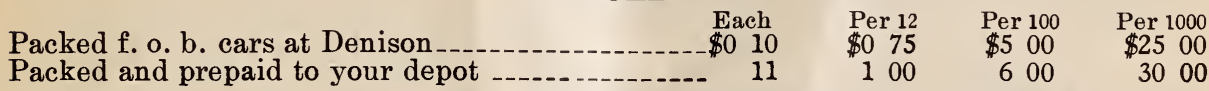

VITIS DOANIANA. From the Panhandle of Texas. Several named varieties.

VITIS LONGII. Of the Red River region of North Texas. Variety Australis.

VALENCIA. Most vigorous, easy rooting, very resistant variety of Vitis Bourquinana or "Southern Aestivalis." A better stock than LeNoir.
VITIS CHAMPINI. Adapted for very hot, dry climate and very limy soils, although does well in any soil. Perfectly resistant and free from all dis€ases. Exceedingly deep-rooting. Ca, supply plants in thousand lots if wanted. Can also supply cuttings of this species at $\$ 10$ per 1,000 for 12 -inch (three or more eyes) cuttings.

All are especially adapted to the Southern States and California. The DOANIANA is especially recommended for limy and black soils, while it does well in any soil. The LONGII is better adapted to sandy soils. Having been engaged for years in supplying vineyardists in France and California with resistant graft stocks for various soils, we understand this matter well, and have spent much time in selecting and producing the above varieties, which we recommend with great confidence. They all grow well from cuttings, and a few vines planted out will soon produce cuttings enough to supply any demand. We produce these only for purpose of introduction, and don't propose to go largely into the graft stock business again.

We have growing in same soil, with same culture, side by side with the above named graft stocks, the most celebrated graft stocks selected and offered for sale by French vineyardists, namely: Riparia Gloire de Montpelier, Riparia Ramon, Riparia x Rupestris 101-14, Riparia x Rupestris 3309, Rupestris du Lot or St. George, Rupestris Ganzin, Rupestris Martin and many others. In every case the varieties we offer are more yigorous, root equally well or better, are fully resistant to phylloxera, and take and carry the graft well, so that there may be no hesitancy in using these stocks in the soils and situations for which they are recommended.

\section{DOMEGRANATE}

SPANISH RUBY. This is a fruiting variety, and probably the finest in cultivation. Fruit 2 to 3 inches in diameter, containing within the rind numerous sprightly juicy berries. Succeeds everywhere within 300 miles of the Gulf.

Each Per 12 (\$) \$3 40

Prepaid

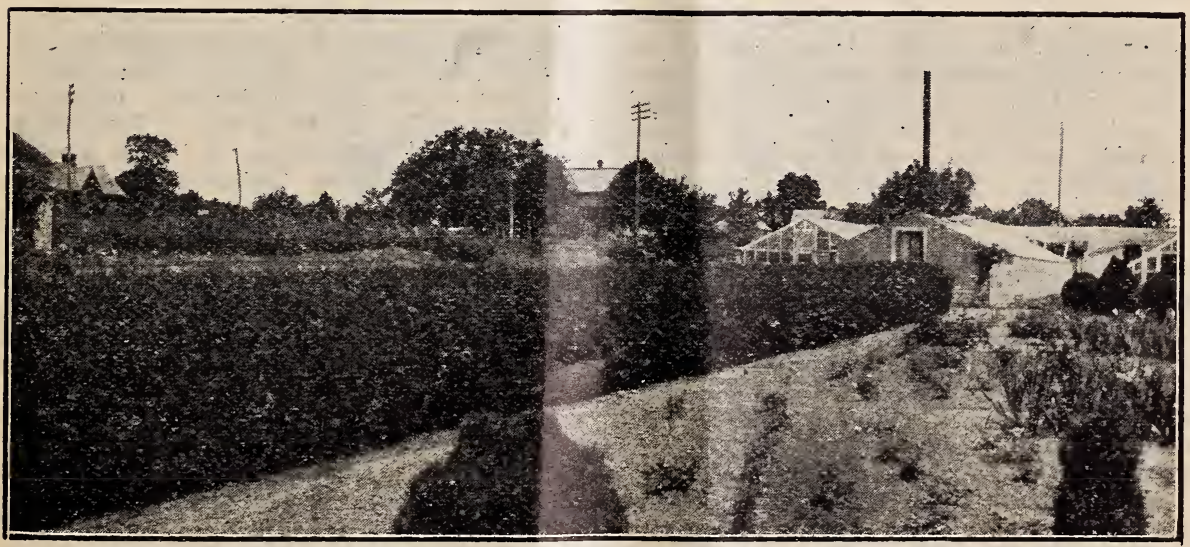

Hedge of the Amour Privet at the Munson Nurseries. 
HEDGING PLANTS PRICES

\begin{tabular}{|c|c|c|c|c|c|c|}
\hline \multirow[t]{2}{*}{ DESCRIPTION } & \multicolumn{3}{|c|}{ F. O. B. Denison } & \multicolumn{3}{|c|}{$\begin{array}{c}\text { Prepaid, if in orders of } \\
\text { not less than } \$ 5.00\end{array}$} \\
\hline & Each & Doz. & 100 & Each & Doz. & 100 \\
\hline $\begin{array}{l}\text { CALIFORNIA PRIVET. One of the most popular; } \\
\text { used for screening or hedging purposes around yards } \\
\text { and lawns; also splendid for single specimens. Nearly } \\
\text { evergreen. }\end{array}$ & & & & & & \\
\hline $\begin{array}{l}1 \text { year, } 1 \text { to } 2 \text { feet } \\
2 \text { years, } 3 \text { to } 4 \text { feet }\end{array}$ & $\$ 0 \begin{array}{ll}\$ 0 \\
15\end{array}$ & $\begin{array}{rr}\$ 0 & 75 \\
1 & 25\end{array}$ & $\begin{array}{rr}\$ 4 & 00 \\
6 & 00\end{array}$ & $\$ 0 \begin{array}{r}15 \\
20\end{array}$ & $\begin{array}{rr}\$ 1 & 00 \\
1 & 50\end{array}$ & $\$ 500$ \\
\hline $\begin{array}{l}\text { A.MOUR PRIVET. A hardier species and more truly } \\
\text { evergreen than the California. Makes a very dense, } \\
\text { handsome hedge and stands shearing remarkably } \\
\text { well. Blooms beautiful spikes of white flowers. } \\
1 \text { year, } 1 \text { to } 2 \text { feet............ } \\
2 \text { years, } 3 \text { to } 4 \text { feet }\end{array}$ & $\begin{array}{l}10 \\
15\end{array}$ & $\begin{array}{ll}1 & 00 \\
1 & 50\end{array}$ & $\begin{array}{l}600 \\
800\end{array}$ & $\begin{array}{l}15 \\
20\end{array}$ & $\begin{array}{l}140 \\
200\end{array}$ & $\begin{array}{rr}700 \\
1000\end{array}$ \\
\hline $\begin{array}{l}\text { TREE PRIVET. We have pruned and trained a lot } \\
\text { of the California Privet into tree forms by removing } \\
\text { all of the lower branches and leaving a top like a tree. } \\
\text { These are rery handsome specimens for lawn or yard, } \\
\text { resembling trained Bay trees, so much admired. } \\
2 \text { years, } 3 \text { feet }\end{array}$ & 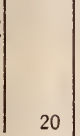 & 200 & 1500 & 25 & 250 & 1700 \\
\hline
\end{tabular}

\section{SHADE AND ORNAMENTAL TREES}

Your chief happiness lies in the growing ornaments surrounding your home. Such ornaments refine and purify. Neglect them not. Plant 20 to 25 feet on sidewalks; 25 to 30 feet apart in yards and parks. Read Waugh's Practical Landscape Gardening. Price, 50c.

\section{PRICES_Unless Otherwise Noted}

Packed f. o. b. cars at Denison
Packed and prepaid to your depot...

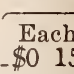

\section{$\$ 015$}

$\frac{20}{\text { Each }}$

Packed f. o. b. cars at Denison

Packed and prepaid to your depot...

AMEIRICAN ELM. Large-leaf elm, healthy, quick growth, long-lived. A desirable shade tree in every way. Sizes from 4 to 12 feet.

BIACK LOCUST. (Sweet Locust.) A splendid dry climate shade, ornamental or grove tree. Every prairie farm should have a grove of this for shade and fence posts. 4 to 12 feet.

DOGWOOD. Large, white flowering. This most beautiful large shrub or small tree, native of the timbered sections of Eastern Texas, has remained greatly neglected by those who decorate their grounds with trees and shrubs. The cause of this is probably the difficulty of transplanting the trees direct from the woods. The nursery-grown trees are readily transplanted. There are few trees more striking and lovely than the Dogwood in spring with its large profuse snow-white flowers, and its bright scarlet berries in fall and winter, besides the tree is very pretty as a spreading shade tree. Sizes 2 to 8 feet.

MAPLE-Soft or Silver. The best; a favorite; quick, handsome, beautiful scarlet in fall. Have a fine stock. Can make low prices on large orders. All sizes up to 14 feet.

\begin{tabular}{|c|c|c|}
\hline $\begin{array}{l}\text { Each } \\
\$ 020 \\
25\end{array}$ & $\$ 175$ & $\begin{array}{r}100 \\
\$ 1500 \\
2000\end{array}$ \\
\hline $\begin{array}{l}\text { Eac } \\
\$ 0\end{array}$ & $\begin{array}{r}\$ 400 \\
5 \quad 50\end{array}$ & \\
\hline uic & 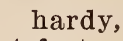 & 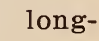 \\
\hline
\end{tabular}

SYCAMORE. Quick, hardy,
ved, no disease. 4 to 14 feet.

THURROW WILLOW. A beautiful weeping tree, healthy, quick growth. Will succeed well on uplands. Price, $25 \mathrm{c}$ each, $\$ 2.50$ per 12 , f. o. b.; $30 \mathrm{c}$ each, $\$ 3$ per 12, prepaid.

VITUS AGNUS-CASTUS INCISA (Mint Tree). A remarkable perpetual-flowering small tree; hardy throughout the South, producing innumerable spikes of rich blue, highly-scented, mint-like flowers, much liked by bees. The leaves are divided like a hand, into five to seven finger-like leaflets. $50 \mathrm{c}$ each, prepaid; $40 \mathrm{c}$, f. 0. b.

YELLOW POPLAR (Tulip Tree), 4 to 14 feet.

MALE RUSSIAN MULBERRY. Nonfruiting. An excellent round-headed shade tree, well adapted for street planting. Sizes 3 to 10 feet.

WEEPING MULBERRY. Have the heads from 3 to 5 feet from the ground from which the branches droop downward. However, the height at which one desire the tree to head can be regulated by pruning as the tree grows. 1 year trees, 50c each; $\$ 5$ dozen. 


\section{PERENNIALS-For Bedding}

\section{PRICES} $\$ 0 \quad 10 \$ 100$

\section{CANNAS}

(Keep the roots in cool, dry place, away from frost. Do not plant in ground until April.)

The following make a most superb collection:

PREMIER. Dwarf, light green, scariet center, bordered with yellow and splotched with scarlet.

AUSTRIA. Tall, green, bright yellow, with minute scarlet hyphons in throat and center.

MLLE. BERAT. Tall, green, clear, pinkish crimson.

J. D. CABos. Tall, purple foliage, salmon.

ALLEMENIA. Tall, green, orange, scarlet, yellow throat penciled with orange, yellow border.

BURBANK. Tall, largest leaves, dark purple. Red, with small red dots in yellow throat.

SECRETARY CHEBANNE. Medium, partly bronze, orange red.

CINNABAR. Medium, light green, orange, scarlet, yellow throat.

FLORENCE VAUGHAN. Dwarf green, bright yellow colored with large red dots.

EGANDALE. Medium purple, dark crimson.

DUIKE OF MARLBORO. Medium green, velvety, bright crimson.

FLAMINGO. Medium green, bright scarlet.

QUEEN CHARLOTTE. Dwarf green, scarlet center, with wire border of light yellow.

Each Per 12

Packed and prepaid......-- $12 \quad 125$

IRIS

The following list of English and German Iris are the very best out of a large list we have tested:

CHALCEDONY. Outer petals purplish violet, streaked; inner petals lavender-pale purple; medium size flowers 4 to 5 inches. Late, profuse, good grower.

L'ELEGANTE. Outer petals dark violet, inner petals pale lavender, blotched with violet; large, 5 to 6 inches. Very vigorous, profuse, medium to late. Very attractive, showy.

IEONIDAS. Outer petals dark violet, inner petals violet. Darkest of all. Fair grower, late.

MARJOLIN. Outer petals streaked maroon, inner petals clear bright lemon yellow. Very late, good grower, profuse. Very showy, valuable.

TRIFLORA. Outer petals violet, inner petals lavender; large; very vigorous, profuse.

THYSPE. Outer petals purplish, inner petals pale purplish yellow; medium size; vigorous.

VICTOR LE NOIR. Outer petals velvety violet, inner petals white; large. Very attractive, showy; vigorous; late.

VICTORIA. Outer petals white, bordered with lavender penciling. Strong grower; earliest of all.

\section{OTHER PERENNIALS}

ZEBRA GRASS. The prettiest and most enduring of all grasses. Crossstriped with thin lines of white. Makes soft plumes in fall.

PAMPAS GRASS. A strong growing grass, producing fine white plumes for winter decoration.

\section{ORNAMENTAL VINES PRICES}

Pach Per 12 Per 100 Packed and f. o. b. Denison _._._._._. Packed and prepaid

CLIMBING ROSES. See list under Roses.

HONEYSUCKLE, Chinese Evergreen. Purplish foliage, flowers buff and white.

HONEYSUCKLE, Halls. White in opening, becoming buff. Very profuse, perpetual from early spring until fall; evergreen.

TRUMPET CREEPER. A stout, woody, handsome vine, with compound leaves and perpetual, waxy, large, tubular orange flowers in clusters; fine to ornament out-houses, tree bodies, etc., as it climbs by aerial roots.

IVISTARIA. American purple. Hardy; fine for arbors, porch screens, etc. Profuse in early spring.

WISTARIA-White. Strong twining vine; blooms in drooping spikes, making a very beautiful mate for the purple. 


\section{EVERGREENS}

\section{PRICES}

Prepald prices are for orders of $\$ 5$ or more. See page 2. Have only the sizes mentioned for each variety.

DESCRIPTION

\section{CONE-BEARING CLASS}

ARBORVITAE. Golden Compacta, round, beautiful in form and color.

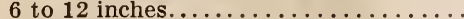

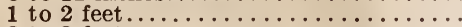

2 to 3 feet............................

ARBORVITAE. Golden Compacta, upright or

pyramidal. Another beautiful form.

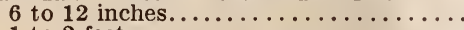

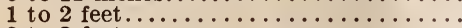

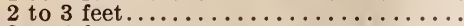

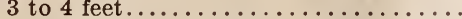

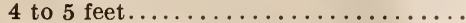

We wish to call attention to our large and choice stock of the two large sizes, the 3 to 4 feet and 4 to 5 feet. They are well shaped and will transplant easily and are ready for immediate effect. Such specimens usually retail for $\$ 2$ to $\$ 5$ each..

ARBORVITAE. Chinese, dark green, more rapid grower than the Golden.

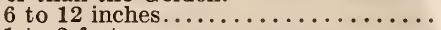

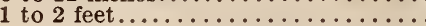

2 to 3 feet.

JUNIPER. Trailing Tamarix-leaved, low, spreading, very hardy, fine for single specimen.

JUNIPER, RED CEDAR One of our best nativ evergreens. Of rapid growth.

6 to 12 inches.

1 to 12 inch

ROSEDALE HYBRID. ' A true hybrid of the Retinospora and the Golden Arborvitae. Resembles the Golden Arborvitae in shape and the Retinospora in color and texture, except that it has a soft touch. One of the most satisfactory evergreens.

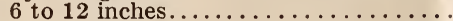

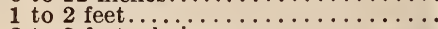

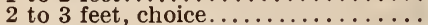

\section{BROAD-LEAVED CLASS}

EVERGREEN TREE BOX. A splendid perfectly hardy evergreen shrub; excellent for cemetery planting and for ornamental screens and hedges. Valuable to plant along narrow walks and in small beds, as it is a very slow grower.

6 inches to 1 foot

EUONYAMUS JAPONICA. Resembles the Tree Box in appearance, only grows faster and has larger leaves. Suitable for lining walks, planting in clumps, or as single specimens. Have two varieties: The solid green and the variegated white and green leaf.

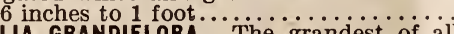

MAGNOLIA GRANDIFLORA. The grandest of all evergreens and flowering trees. Has large, glossy, bright green leaves. Succeeds through out Texas and Indian Territory, as well as in other Southern States. By clipping off all but a few of the tip leaves when taken up. and treated as in our handling, they are readily transplanted. We do not elip the leaves off unless so instructed.

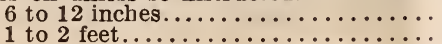

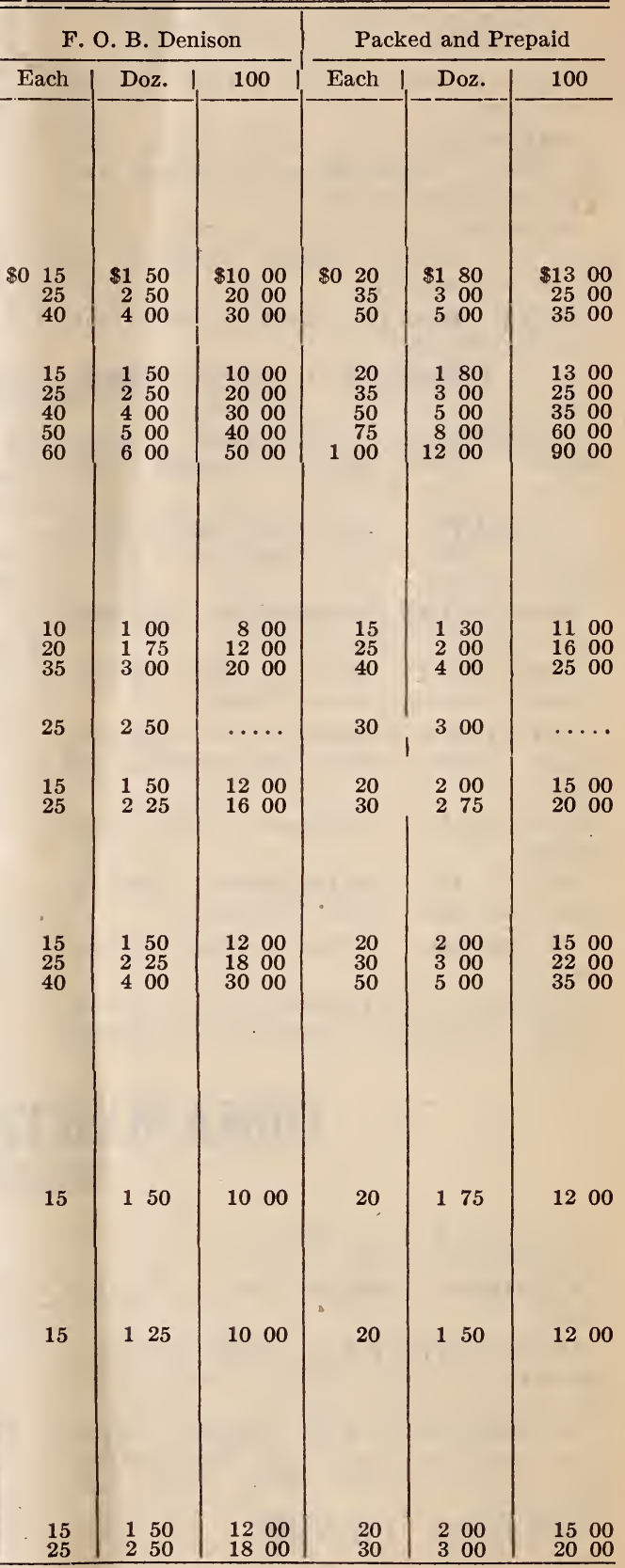




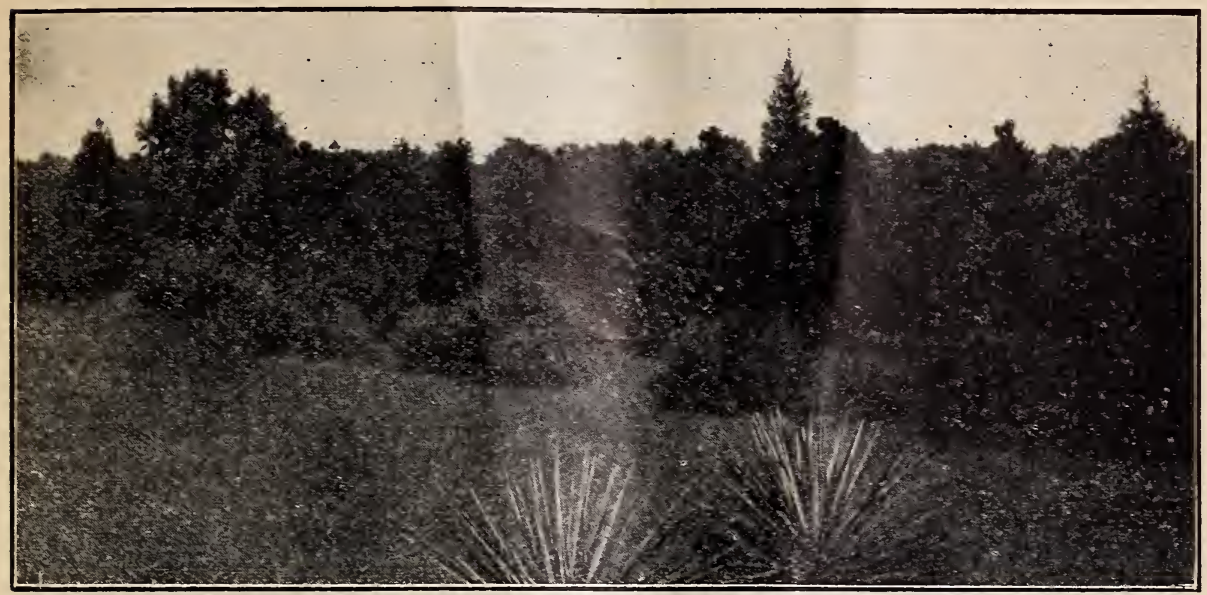

Arboretum at the Munson Nurseries.

\section{FLOWERING SHRUBS} DRICES_Prepald prices throughout the catalogue are scaled for orders of $\$ 5.00$ or

\section{DESCRIPTION.}

ALTHEA, DOU BLE IVHITE. (Rose of Sharon.) Upright, large,

double flowers; blooms in midsummer
ALMOND, DOUBLE FLOWERING. Pink: low, roundish, corered with flowers early in season-... Imperial Pink and Crimson; splendid summer bloomers, grow to be large shrubs; hardy as far north as Kansas.-

CRAPE-MIYTLE. White; a little more spreading in habit than the pink or crimson; fine summer bloomer-

DEUTZIA CRENATA. Upright shrub; easy to grow and trans plant, double pink; blooms early

DEUTZIA WATSONII. (Syn. Pride of Rochester.) Very double, pure white, profuse; finest of all deutzias; upright growth

FLO IVERING WILLOW, so-called (Chilopsis Saligna). A fine treelike shrub, blooming profusely from spring on all through the summer, even in the hottest weather. Flowers tubular, 1 to 2 inches

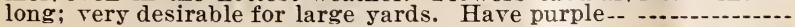

LILAC. Varieties: DeMorley, Prince Notger, Rothinger; a large cluster of small flowerlets. Quite fragrant

PHILADElPHUS. (Syringa, Mock Orange of the North.) Blooms early, very pretty pure white flowers, profuse, sweet; upright

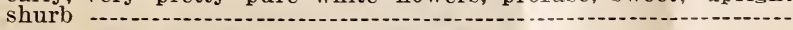

PYRUS JAPONICA. (Scarlet or Japan Quince, Deril's Fire.) A gorgeous sight of fiery red flowers very early in spring; in full bloom before leares come out. Fine for single specimen, screen or hedge

POMEGRANATE. Double Scarlet and Double Salmon; large Taxylike beautiful flower. Half Hardy in North Texas; hardy in Texas south of Tyler, Hempstead and Austin-....................................

SPIREA BILLARDII. Upright shrub, rose-pink colored spikes; rery pretty and effective in bouquets; profuse, blooms most of PIREA REEVESII. (Bridal Wreath.) Large round clusters of

SPIREA REEVESII. (Bridal Wreath.) Large round clusters of early spring. More desirable than the Snowball shrub............

SPIREA ARGENTEA. A good mate for the Billardii as the spikes of flowers are the same shape of the Billardii, only the Argentea

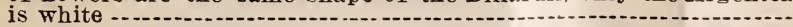

SPIREA PRUNIFOLIO. Snow white double flowerlets; covering all of the branches, very early

SPIREA THUMBERGII. Foliage rery fine. Flowers white.

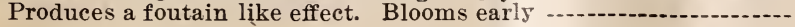

\begin{tabular}{|c|c|c|c|}
\hline \multicolumn{2}{|c|}{$\begin{array}{l}\text { Packed f́.o.b. } \\
\text { Denison. }\end{array}$} & \multicolumn{2}{|c|}{$\begin{array}{l}\text { Packed and } \\
\text { Prepaid. }\end{array}$} \\
\hline Each. & Doz. & Each. & Doz. \\
\hline$\$ 025$ & $\$ 250$ & $\$ 030$ & $\$ 300$ \\
\hline 25 & 250 & 30 & 300 \\
\hline 25 & 225 & 30 & 275 \\
\hline 35 & 400 & 40 & 450 \\
\hline 15 & 150 & 20 & 175 \\
\hline 15 & 150 & 20 & 175 \\
\hline 25 & 250 & 30 & 380 \\
\hline 20 & 200 & 25 & 225 \\
\hline 15 & 150 & 20 & 180 \\
\hline 15 & 150 & 20 & 180 \\
\hline 20 & 200 & 25 & 250 \\
\hline 15 & I 50 & 20 & 175 \\
\hline 25 & 225 & 30 & 275 \\
\hline 15 & 175 & 20 & 200 \\
\hline 25 & 200 & 30 & 250 \\
\hline 25 & 225 & 30 & 275 \\
\hline
\end{tabular}




\section{ROSES}

Read Henderson's Practical Floriculture. Price, $\$ 1.50$

\section{PRICES_Except Varieties otherwise noted}

$\begin{array}{lrr}\text { Pach } & \text { Per } 12 & \text { Per } 100 \\ \text { Packed and f. o. b. Denison } & \$ 200 & \$ 1200 \\ \text { Packed prepaid to your depot } & 20 & 1500\end{array}$

\section{STRONG, ODEN-GROUND, TWO-YEAR PLANTS}

The following list includes the most superb varieties, both old and new. The plants are thrifty and vigorous, growing in open ground.

All these have been in bloom throughout the season, and we know them to be strictly pure and true to name and description. Our roses always give the best of satisfaction.

\section{EVERBLOOMING WHITE AND BLUSH}

BRIDE. Strong, healthy, large, double, fine bud; delicate carmine blush.

CARNOT. Flesh-tinted white. Long beautiful bud, cupped, wax-like.

CLOTHILDE SOUPERT. Vigorous, profuse bloomer, with medium, very full, white flowers, with pink center.

THE QUEEN. Pure snow-white; sweet and fragrant; petals are thick; makes fine buds on long stems; good grower.

KAISEIRIN AUGUSTA VICTORIA. Pure white, fragrant; fine buds and flowers on long stems; profuse; strong grower.

WHITE COCHE'T. Identical in shape and habit with that splendid pink rose, Maman Cochet, except the color is white, changing to blush.

\section{BUPF AND YELLOW}

MAD. WELCHE. A fine, rich, fragrant, cream salmon center.

PERLE DES JARDINS. A fine, rich yellow. Flower very double and fragrant. Pretty bud.

ETOILE DE LYON. Rich, yellow, full, fragrant, pretty; profuse all summer, during hottest weather; good grower.

\section{PINK}

BRIDESMAID. Sport of the Catherine Mermet; bright pink, beautiful bud; free bloomer.

LA FRANCE. Strong, upright, very large, full; delicate pink, sweet, profuse.

DUCHESS OF ALBANY. Habit of plant, shape and size of flower similar to that of La France, but more profuse and of deeper pink.

FRANCESKA IRUGER. Fine rich pink, creamy towards center; slightly penciled with deeper pink on outer petals. Healthy plant, great bloomer.
MAMAN COCHET. Rose or pink, shaded with salmon; profuse, fine bud and flower; strong grower; a very superior rose; one of the best for outdoor planting in Texas, also excellent for cut flowers.

PERNET TRIUMPH. Rich, dark, bright pink; large, beautiful bud on strong stem.

PAUL NEYRON. Large, clear pink. Plant vigorous.

\section{SCARLET AND CRIMSON}

AMERICAN BEAUTY. Crimson, fine, 50 cents each, $\$ 5.50$ per dozen, f. o. b.; 55 cents each, $\$ 5.75$ per dozen, prepaid.

METEOR. Large, clear, rich, dark crimson; profuse; strong grower, full.

MADAME MASSON. Strong and hardy; flowers large and profuse, very double; flowers dark crimson.

PIERRE GUILLOT. A rival of American beauty in beautiful crimson flowers, and a freer bloomer.

\section{HARDY CLIMBERS}

TENNESSEE BELLE. Good climber; medium, full; blush; in clusters; profuse in spring.

CRIMSON RAMBLER. One of the finest climbers; magnificent trusses of deep crimson flowers; makes a fine show as a climber and profuse bloomer.

CLIMBING PAUL NEYRON. Large flower, pink; constant. A superb variety, a fine companion for the next variety.

CIIMBING AUGUSTA VICTORIA. Most beautiful white bud, and flower equaling in beauty the bush Kaiserin Augusta Victoria; constant.

CLIMBING METEOR. A deep, double crimson climber. Constant in flower.

CLIMBING CLOTHILDE. Flowers borne in clusters and of same size and color as Clothilde Soupert. Hardy. 


\section{...ORDER SHEET...}

Read carefully every paragraph on pages 1 and 2 of body of catalogue

Remember that the prepaid rates on single and dozen items are for orders of $\$ 5$ or more and within the States named on page 2 of catalogue, under "We Prepay Freight," which be sure to read.

It is a distinct agreement between us and our customers that in any case where stock fails to come up to the specifications, we are liable only to replace stock or refund money received for goods in question. But no pains are spared to do a reliable business. or draft.

Please fill out blank with your order, and mail with remittance per postal or express order

\section{T. V. MUNSON \& SON, DENISON, TEXAS :}

For the amount remitted herewith, $\$ \ldots \ldots \ldots \ldots \ldots \ldots \ldots \ldots \ldots \ldots \ldots \ldots$ flease fill the following list, if your stock will permit. If some of the varieties ordered are out of stock, then please fill my order as follows: (Make a cross $(x)$ before the one of the four numbered directions below which you wish us to follow, in case any of the varieties ordered are out.)

1. For the varieties not in stock, substitute others of equal or better value of same season.

2. Fill order as specified as near as stock will permit, and return money or give credit for varieties not in stock.

3. Hold order, write and name varieties not in stock, so another selection can be made.

4. Return order and money without filling any part of order.

Ship by

to Station

Care of

P. $O$.

County

State

Name

No.

Street or Avenue, or R. F. D

(State which scale of Prices you have selected, f. o. b. or prepaid.)

\section{LIST OF ARTICLES}

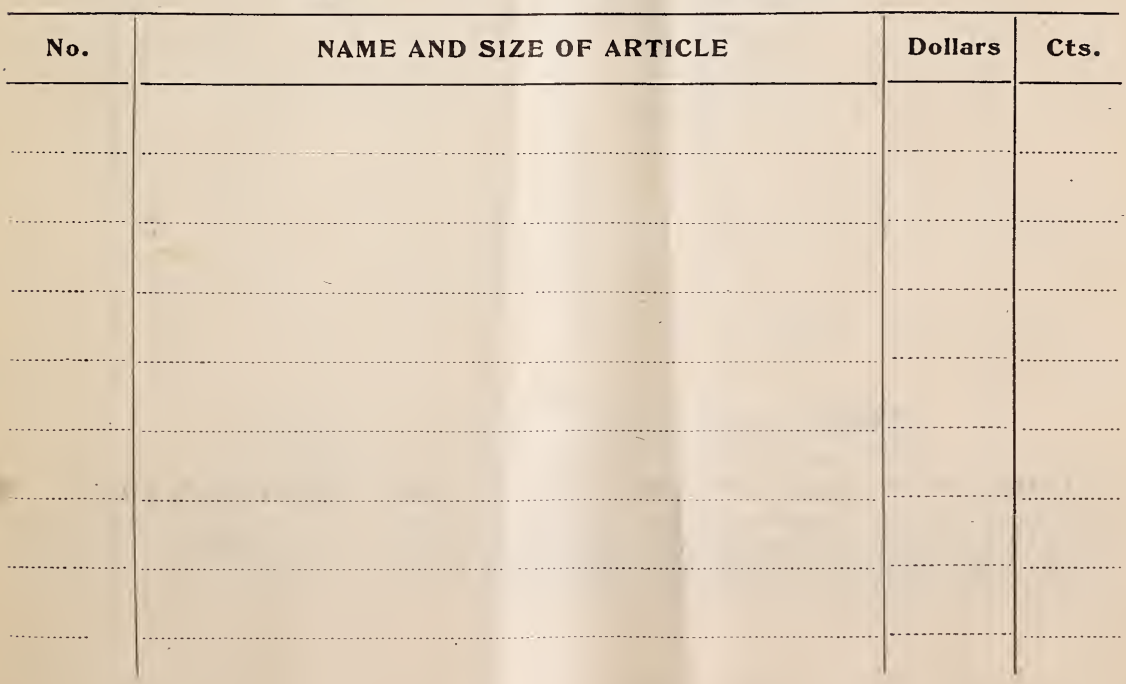


ORDER SHEET-Continued

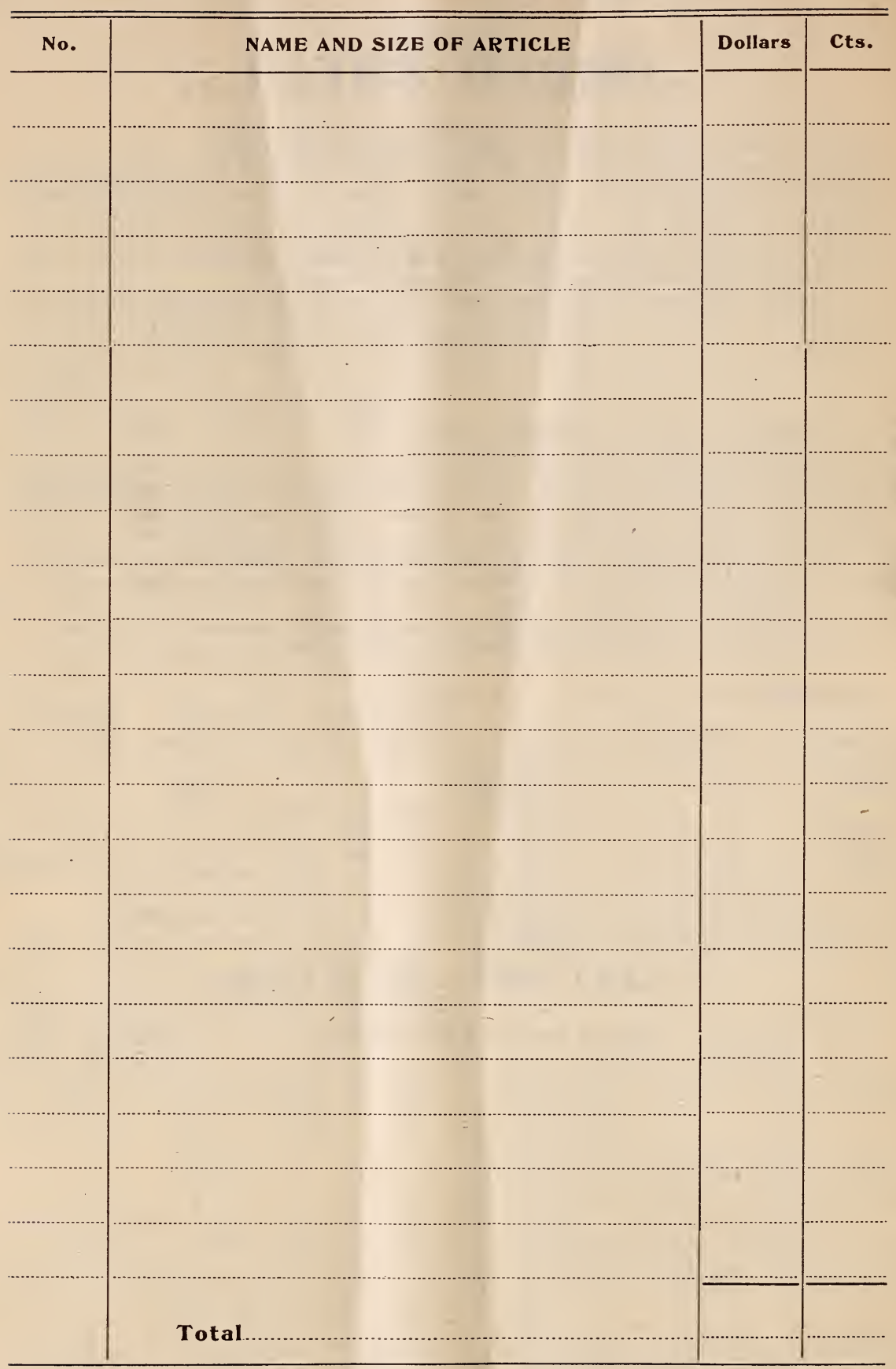

(If this sheet is not sufficient, continue same form on blank paper.)

C A U T I O N . - Put list of Home Improvers on separate sheet of paper from that of your letter or order. Let your letter be separate from the order sheet, as this will avoid confusion. Above all, write plainly, especially your name and address. 


\section{...INDEX...}

\begin{tabular}{|c|c|}
\hline Page & Grapes- \\
\hline $\begin{array}{l}\text { orticultural Information............... } 2 \text { d cover } \\
\text { Small Library of the most Useful }\end{array}$ & $\begin{array}{l}\text { Standard Varieties.... } \\
\text { Munson Varieties }\end{array}$ \\
\hline Horticultural Books.......................2d corer & $\begin{array}{l}\text { Munson I arieties.......... } \\
\text { Southern Iuscadines... }\end{array}$ \\
\hline Cerms, Conditions, Shipping, etc.......... 1-2 & Vinifera Varieties ... \\
\hline Prices, How to Use Our Scale ............... 2 & New Creations in American \\
\hline Apples & 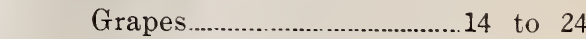 \\
\hline rab Apples............ & A New Departure in Grape Hybrids, \\
\hline 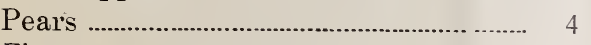 & La Salle and San Jacinto............. 12 \\
\hline Figs & Resistant Graft Stock for Grapes.. \\
\hline Quinces ...................... & Japanese Persimmons. \\
\hline 5 & Pomegranate.. \\
\hline Sherries... & Hedging Plants \\
\hline 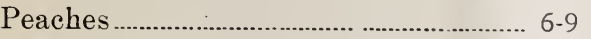 & Shade and Ornamental Trees... \\
\hline ............. 9-10 & 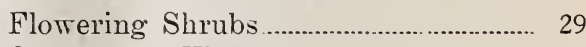 \\
\hline Mulberries ..................... & 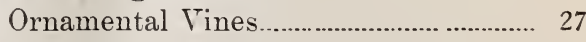 \\
\hline Blackberries.. .............................................. 10 & 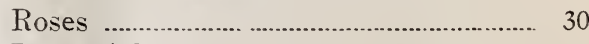 \\
\hline 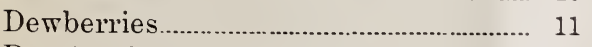 & 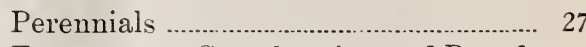 \\
\hline Raspberries.. .................... & Evergreens-Cone-bearing and Broad- \\
\hline 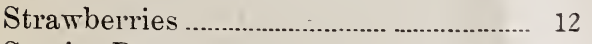 & leaved \\
\hline Service Berry ............... & Order Sheet ......... \\
\hline
\end{tabular}

\section{Pot Plants, Cut Flowers, Floral Designs}

The Munsen Green Houses, Will B. Munson, Proprietor, can supply in their proper season such plants as:

$\begin{array}{ll}\text { Asparagus Spregerii, } & \text { Ferns in Assortment, } \\ \text { Asparagus Plumosa, } & \text { Geraniums, } \\ \text { Begonias, } & \text { Heliotropes, } \\ \text { Carnations, } & \text { Ageratums, } \\ \text { Coleus, } & \text { Pansy Plants, } \\ \text { Cannas, } & \text { Poinsettias, } \\ \text { Chrysanthemums, } & \text { Palms, } \\ \text { H'uchsia, } & \text { Tritomas, Etc. }\end{array}$

A list of such plants, ready in March, mailed free on application.

Can also supply Cut Flowers, Funeral and other floral designs at any time. Prices of designs from $\$ 1.00$ to $\$ 30.00$, according to pattern, size, etc. 'Phone and mail orders will have prompt attention. ADDRESS

WILL B. MUNSON, Denison, Texas

\section{Addresses of Home Improvers Daid for}

If you will send us with your order the names and postoffice addresses of six of your neighbor's who own and are improving their homes, we will put in with your order, if as much as $\$ 2$ or over, articles from our list, of your own selection, to the amount of 25 cents. For 12 such addresses, when order is $\$ 3$ or more, articles to the amount of 50 cents. This order does not extend to more than twelve addresses from one customer. 


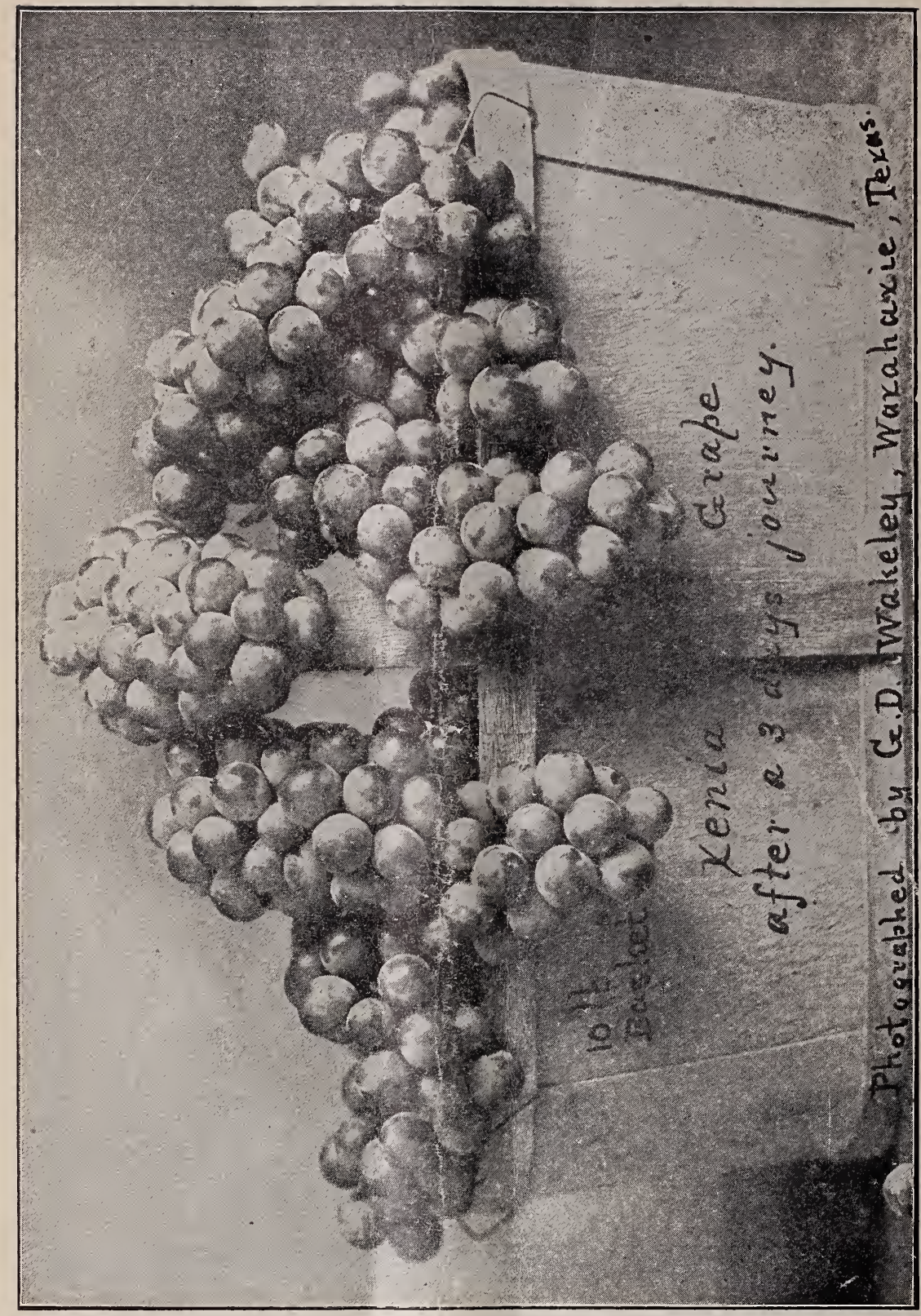

0
0
0
0
0
0
0
0
0
0
0
0

Gold Medal and Diploma awarded us on Fruit Display by the Universal Exposition, St. Louis, 1904 , and Bronze Medal and Diploma on Evergreens. 